\title{
Transportation R\&D Included in Thermal and Mechanical Sciences Program
}

Argonne National Laboratory is a multiprogram, research and development laboratory operated by The University of Chicago for the U.S. Department of Energy. At Argonne, applied research in thermal and mechanical sciences is performed within the Thermal and Mechani-f cal Sciences Section of the Energy Technology Division. Current program areas include compact evaporators and condensers for the process and transportation industries, ice slurrics for district cooling, advanced fluids for improved heat transfer and reduced pressure drop, flow- $\checkmark$ induced vibration and flow distribution in shell-and-tube heat exchangers, and dynamics and control of maglev systems. In general, the objective of the research is to extend the technology base in each of these areas and to facilitate its application in solving problems of impor-s tance to U.S. industries and utilities. This is accom-\& plished by developing validated design correlations and predictive methods.

The staff of the Thermal and Mechanical Sciences Section have extensive expcrimental and analytical expcrience in heat transfer, multiphase flow, structural dynamics and control, fluid-structure interaction, tran- $\$$ sient flow and mixing, thermally driven flows, and flow visualization using ultra-high-speed video. Large, gen-\$r eral-purpose test facilities and smaller, single-purpose test apparatuses are available for experiments and component design evaluation. A world-class capability in the study of flow-induced vibrations exists within the Section.

The U.S. Department of Energy is encouraging Argonne to work with industry for the purposes of transferring technology developed at the Laboratory to industry, and contributing to the development of new and/or improved componenis and processes. Such industrial interaction is expected to improve the competitiveness of U.S. industry in world markets and to create jobs. Various arrangements for working with industrial companies are available. These include Cooperative Research and Development Agreements or CRADAs (parties share the cost of research and the company may elect to retain ownership of any resulting intellectual property it devclops), Work for Others $R \& D$ (the company pays full costs and retains commercial rights to intellectual propcrty), and Personnel Exchange (typically six months to one year-the company pays its share of costs).

For general information on the programs and capabilities of Thermal and Mechanical Sciences and on opportunities for industry to work with the Section on problems in the research areas described above or on related problems of specific interest:

\section{Contacts}

For technical information, contact Martin W. Wambsganss, Thermal and Mechanical Sciences Section, Energy Technology Division, Argonne National Laboratory, 9700 South Cass Avenue, Argonne, Illinois 60439. Phone: (708) 252-6144; Fax:(708) 252-5568.

For information on working with Argonne, contact the Industrial Technology Development Center, $9: 00$ South Cass Avenue, Argonne, Illinois 60439. Phone: (800) 6272596; Fax: (708) 25i2-5230.

Individual fact sheets, describing currently active research program areas, related facilities, and listing, as a contact, the principal investigator, are available.

\section{DISCLAIMER}

This report was prepared as an account of work sponsored by an agency of the United States Government. Neither the United States Government nor any agency thereof, nor any of their employees, makes any warranty, express or implied, or assumes any legal liability or responsibility for the accuracy, completeness, or usefulness of any information, apparatus, product, or process disclosed, or represents that its use would not infringe privately owned rights. Reference herein to any specific commercial product, process, or service by trade name, trademark, manufacturer, or otherwise does not necessarily constitute or imply its endorsement, recommendation, or favoring by the United States Government or any agency thereof. The views and opinions of authors expressed herein do not necessarily state or reflect those- of the United States Government or any agency thereof.

$$
\text { isclunded. }
$$

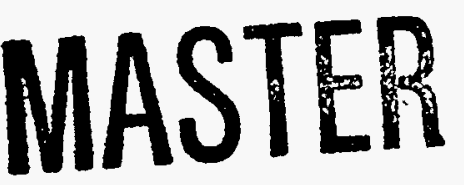




\section{DISCLAIMER}

Portions of this document may be illegible in electronic image products. Images are produced from the best available original document. 


\section{Driving a "Laboratory" Around a Lab}

If your home can be your castle, then perhaps a car can be a laboratory. In fact, Argonne National Laboratory employees driving test vehicles at Argonne's Illinois site are working in moving laboratories. The employees are participating in an experiment to evaluate cars and trucks running on fuels other than gasoline.

With more than 35 vehicles, Argonne's Center for Transportation Research is the nation's largest alternative-fuels fleet demonstration center. Included are vehicles powered by methanol (alcohol derived from natural gas or wood), ethanol (alcohol made from grain), and natural gas.

Alternative fuels are one way to minimize exhaust emissions (hydrocarbons, carbon monoxide, and nitrogen oxides) that contribute to air pollution and global warming. Federal law requires that alternative-fuel vehicles be included in government automobile fleets beginning in 1997 and in private flects beginning in 1998.

Argonne employees use the cars powered by alternative fuels in their daily work, which is as varied as hauling equipment and driving to meetings. The information gathered about the daily performance of the cars aids not only federal agencies that will purchase these types of cars, but car makers and others as well. The information will be available to researchers through a computer data base.

Argonne's alternative-fuels fleet includes mid- and fullsized sedans, burning either ethanol or methanol, and vans and trucks using natural gas. Gasoline-powered vehicles of the same type are used to gather comparison data. The experiment runs for three years.

Most of the flexible-fuel vehicles use methanol during the experiment, but they are flexible because they can use any mix of gasoline and alcohol without modifications. Three flexible-fuel cars use ethanol and gasoline only.
Drivers log mileage and performance for each trip taken. These data and vehicle fuel economy and maintenance records are compiled. Argonne is analyzing additional information on performance, average outdoor temperatures, and emissions for a more precise evaluation of various vehicles and types of fuels and weather.

In an earlier stucy, Argonne drivers logged more than 1 million miles in methano!-fucled vehicles.

\section{Contacts}

For technical information, contact Bob Larsen, Center for Transportation Research, Energy Systems Division, Argonne National Laboratory, 9700 South Cass Avenue, Argonne, Illinois 60439. Phone: (708) 252-3735; Fax: (708) $252-3443$.

For information on working with Argonne, the Industrial Technology Development Center, Argonne National Laboratory, 9700 South Cass Avenue, Argonne, Illinois 60439. Phone: (800) 627-2596; Fax: (708) 252-5230.

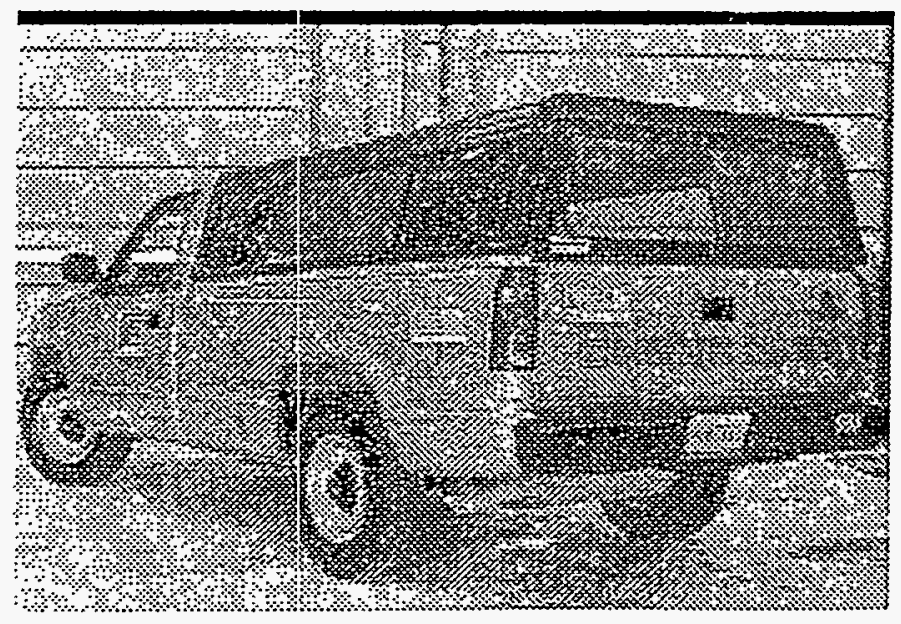

Argonne's alternotive-fueled demonstration fleet includes mid-and full-sized sedans, yans, and trucks. Shown here is a Chevrolet natural gas-powered truck. 


\title{
Recovering Zinc from Galvanized Scrap
}

\author{
A new technology for converting galvanized steel scrap into clear' scrap for steelmaking \\ can save millions in raw-material costs, as well as in environmental compliance.
}

\section{Opportunity}

Half of the zinc produced in the United States is derived from scrap. With zinc-coated scrap having increasing nine-fold since 1980, stcelmakers are feeling the effect of increased contaminant loads on their operations. The greatest concern is the cost of treatment before disposal of waste dusts and water that arise from remelting zinccoated scrap. An economical process is needed to strip and recover the zinc from scrap to prepare it for steelmaking.

\section{Argonne Solution}

Through a cost-sharing program with Metal Recovery Industries U.S., Inc., Argonne National Laboratory is developing a new technology for converting galvanized steel scrap from stamping plant wastes into clean scrap for steclmaking. With further development, the technology could also process galvanized steel scrap from automobiles.

\section{Advantages}

Argonne estimates the operating-cost benefits to a steelmaker to be $\$ 140$ million per year (compared to using non-scrap sources of iron). Environmental compliance costs would be mitigated by about $\$ 150$ million per year. Foreign exchange could also benefit by some $\$ 130$ million per year, through reductions in zinc imports.

\section{Technical Concept}

The process consists of dissolving the zinc coating from scrap in a hot, caustic solution and recovering the zinc from the solution electrolytically. The zinc-bearing scrap is charged into an electrolytic cell containing a $70^{\circ} \mathrm{C}$ to $90^{\circ} \mathrm{C}$ sodium hydroxide solution. Applying an electric potential dissolves the zinc into the hot caustic. Clean scrap is removed, rinsed, and recycled. The electrolyte is then pumped into a second cell, where the zinc is electrolytically removed from solution. The zinc can be sold to refiners for purification and resale.

\section{Status}

Metal Recovery Industries has installed a 50,000 tonper-year pilot plant in East Chicago, Indiana. This plant has dezinced over 1,000 tons of automotive stamping waste, and tests have demonstrated that the process can remove not only zinc but also many plastic coatings.
Tests continue to evaluate process economics and operation.

\section{Future Plans}

Plans are to refurbish the pilot plant and to provide 1,500 tons of dezinced scrap for a melt test to determine the environmental impact of dezinced scrap on furnace operations. If testing is successful, detailed engineering will begin on a 200,000-ton dezincing demonstration plant for late 1996. Plants like this one could be used for future commercia! operations.

\section{Contacts}

For technical inforrnation, contact Frederick J. Dudek, Process Evaluation, Energy Systems Division, Argonne National Laboratory, 9700 South Cass Avenue, Argonne, Illinois 60439. Phone: 708/252-7797; Fax: 708/252-3443.

For information on working with Argonne, contact the Industrial Technology Development Center, Argonne National Laboratory, 9700 South Cass Avenue, Argonne, Illinois 60439. Phone: (800) 627-2596; Fax: 708/2525230 .

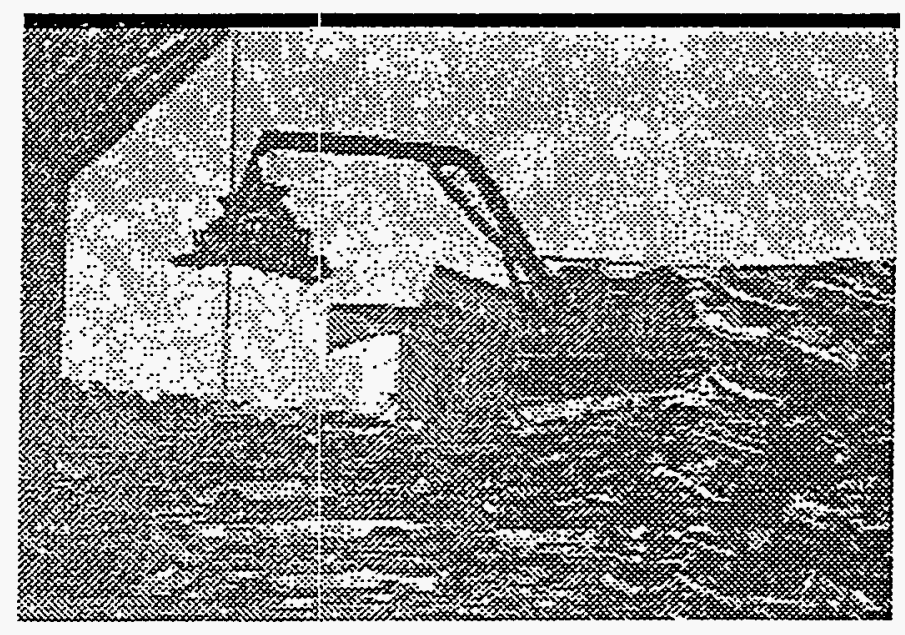

In partnership with Metal Recovery Industries U.S., Inc, Argonne National Laboratory is developing a new technology for converting galvanized steel scrap from stomping plant wastes into clean scrap for steelmoking. With further development, the technology could also process galvanized steel scrap from automobiles. 


\section{Using Monatomic Nitrogen to Reduce $\mathrm{NO}_{x}$ in Engine Exhaust}

\section{Opportunity}

During the combustion of fuel in an engine, oxides of nitrogen are formed (temperature must $j x$ in excess of $\left.2300^{\circ} \mathrm{F}\right)$ :

$$
\mathrm{N}_{2}+\mathrm{O}_{2} \longrightarrow 2 \mathrm{NO}+\text { other oxides of nitrogen }
$$

When the temperature is below $1300^{\circ} \mathrm{F}$, a reverse reaction takes place when monatomic nitrogen is present:

$$
2 \mathrm{NO}+2 \mathrm{~N} \longrightarrow 2 \mathrm{~N}_{2}+\mathrm{O}_{2}
$$

Monatomic nitrogen could be used in an after-treatment scheme to reduce $\mathrm{NO}_{x}$ in engine exhaust. However, monatomic nitrogen is unstable and cannot be stored.

\section{Argonne Solution}

As part of its work on applying oxygen-enriched air to internal combustion engines, Argonne National Laboratory is investigating the use of membrane separation. The oxygen-enriched air coming from the membrane is used to improve engine combustion. The membrane "waste stream," which contains nitrogen-enriched air, could be used as feedstock for producing monatomic nitrogen.

Argonne is testing pulsed-spark and steady-spark methods of electrically activating the nitrogen. The goal is to develop a cost-effective electrical activation device for engine and vehicle applications.

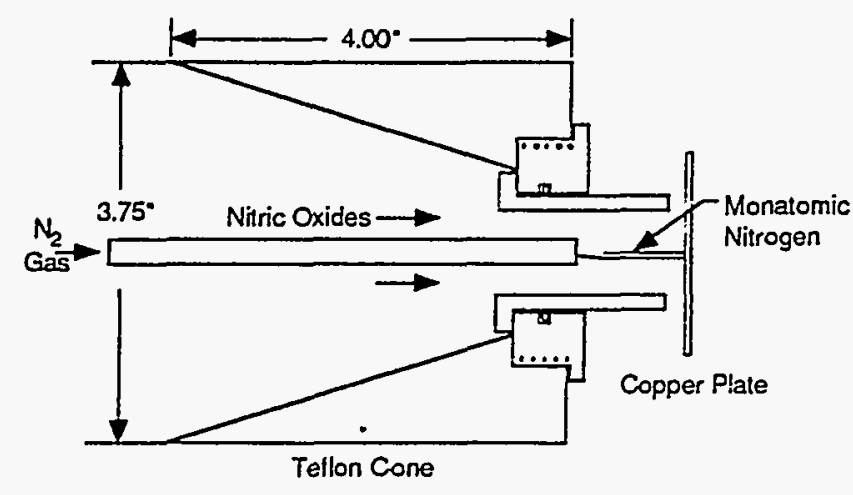

Nitric oxide reduction with activated nitrogen experimental setup - Reaction Chamber

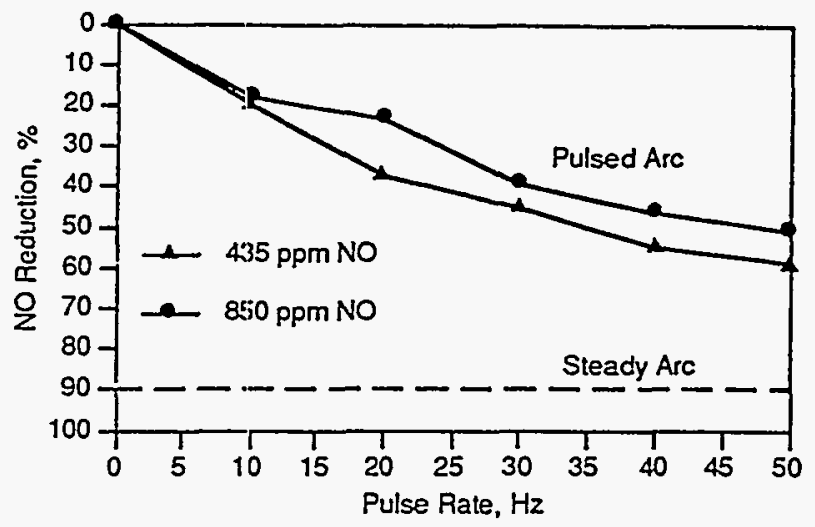

Nitric oxide reduction with activated nitrogen optimized reaction chamber

\section{Status}

Fifty to $90 \%$ reductions of $\mathrm{NO}_{x^{\prime}}$ even in the presence of oxygen, have been demonstrated, which indicates that this technique could be used to control $\mathrm{NO}_{x}$ in gasoline engines. Tests with $\mathrm{NO}_{2}$ and oxygen mixtures, as well as with synthetic gasoline engine exhaust, will be conducted. Actual engine testing will follow.

\section{Contacts}

For technical information, contact Raj Sekar, Center for Transportation Research, Energy Systems Division, Argonne National Laboratory, 9700 South Cass Avenue, Argonne, Illinois 60439. Phone: (708) 252-5101; Fax: (708) 252-3443.

For information on working with Argonne, contact the Industrial Technology Development Center, Argonne National Laboratory, 9700 South Cass Avenue, Argonne, Illinois 60439. Phone: (800) 627-2596; Fax: (708) 2525230 . 


\title{
Developing Boric Acid As a Self-Replenishing Solid Lubricant
}

\author{
Boric acid helps conserve energy and reduces wear in gear:s, bearings, drives, \\ and other transportation-related parts.
}

\section{Opportunity}

With its unique laycred-crystal structure, boric acid has sclf-lubricating properties that make it superior to many other solid lubricants, such as graphite or molybdenum disulfide. Friction tests show that boric acid can provide friction coefficients as low as 0.02 to 0.05 , one-fourth to one-sixth of the value obtained with other, more expensive solid lubricants.

\section{Argonne Solution}

Argonne National Laboratory is developing boric acid as a self-rcplenishing solid lubricant.

\section{Advantages}

Boric acid is abundant, inexpensive, nontoxic, and cnvironmentally safe. Potential applications for its use as a lubricant include gears, bearings, and metal-forming or metal-cutting machines. Used as a lubricant in mechanical assemblies, boric acid outperforms competing products. It may also be mixed with existing liquid and solid lubricants; then, if the conventional lubricant is inadequate, boric acid becomes active as a backup lubricant.

\section{Technical Concept}

Moisture is generally detrimental to the action of such lubricants as molybdenum disulfide, but it plays a key role in the self-replenishment of boric acid. When boric oxide is exposed to open air, a reaction layer of boric acid spontaneously forms on the surface, reacting with the moisture in the air to provide a self-renewing lubricating layer.

The self-lubricating mechanism of boric acid is governed by its special crystal structure. It crystallizes as a layered compound in which atoms in each layer are tightly bonded to each other. The layers themselves are weakly bonded; when stressed, they shear and/or slide over one another with relative ease, so friction is low. Moreover, the strong intra-layer bonding prevents direct contact between sliding parts, minimizing wear.

\section{Status}

Currently, Argonne is licensing this technology for a variety of industrial applications. One application of interest is the use of a boric acid coating as a metalforming, solid lubricant. Argonne researchers believe that

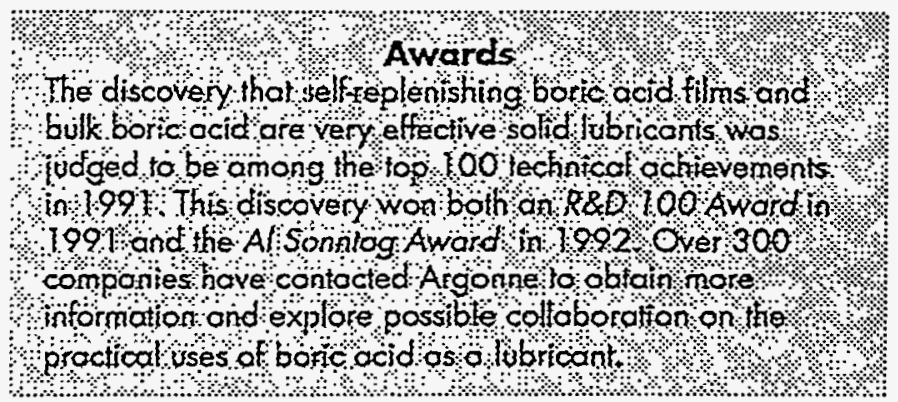

boric acid could make an ideal substitute for current phosphate lubricants used to cold-form steels and other metals. Boric acid offers a much simpler application and stripping/removal process and an edge in environmentally safe disposal of waste streams. Argonne is seeking to team up with industrial partners to commercialize the use of boric acid for automotive applications.

\section{Contacts}

For technical information, contact Fred A. Nichols, Tribology Section, Energy Technology Division, Argonne National Laboratory, 9700 South Cass Avenue, Argonne, Illinois 60439. Phone: (708) 252-8292; Fax: (708) 2524798.

For information on working with Argonne, contact the Industrial Technology Development Center, Argonne National Laboratory, 9700 South Cass Avenue, Argonne, Illinois 60439. Phone: (800) 627-2596; Fax: (708) 2525230.

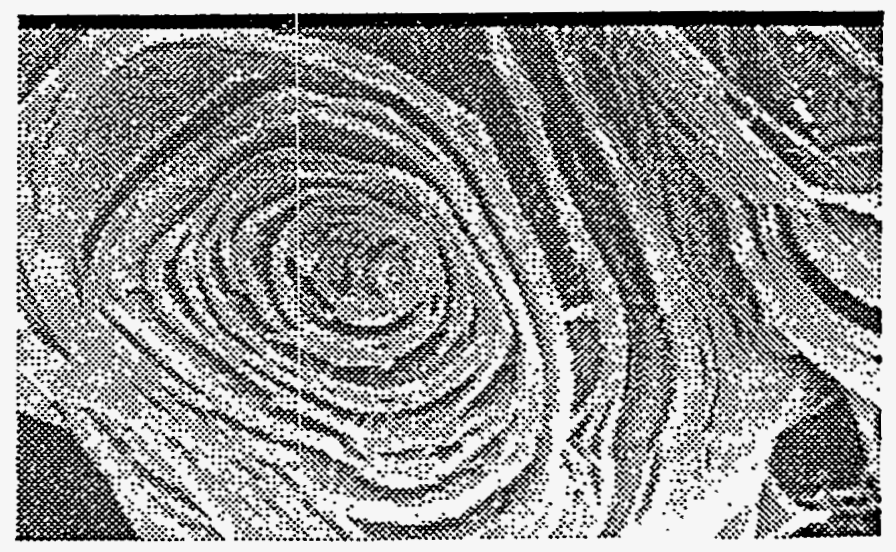

The picture shows a high-magnification photograph of boric acid crystals. 


\title{
Lightweight Materials for Passenger Cars and Trucks
}

\author{
Aluminum and other lightweight materials have a significant role to play in improving the performance and fuel \\ economy of passenger cars and trucks. Argonne is evaluating an all-aluminum car body for Ford Motor Co.
}

\section{Opportunity}

Over the last two decades, automotive manufacturers have used plastics extensively to reduce the weight of cars. When substituted for steel in automobiles, such lightweight materials as aluminum hold great promise for improving the fuel cconomy of passenger vehicles.

\section{Argonne Solution}

Argonne National Laboratory has examined the potential benefits of aluminum, advanced polymer composites, magnesium, and ceramic materials as substitutes for stecl in automotive structural and sheet applications and in engine parts. Argonne's conclusion: the widespread use of such materials has the potential to increase fuel economy significantly, even without vehicle downsizing.

Recently, Argonne received an aluminum-intensive Mercury Sable from Ford Motor Co. for evaluation. Over a period of three and one-years, Argonne will assess the fuel consumption and other operational characteristics of this type of car.

\section{Advantages}

Substituting aluminum for steel in a midsize car body reduces its mass by some 400 pounds. However, even greater reduction can be realized in cars designed around the use of

aluminum; the engine and other major components would be correspondingly downsized or lightened, and total mass savings would approach 1,000 pounds. Such a reduction in mass would mean very significant increases in fuel economy.

Aluminum has the added benefit of possibly lasting longer than steel in a car body.

\section{Technical Concept}

Argonne researchers have projected the market shares that lightweight-material-intensive vehicles could achieve in the United States. Argonne's computer model predicts significant inroads for lightweight vehicles among typical consumers, with consequent high savings in energy consumption.

In the case of aluminum car bodies, other issues are being investigated besides fuel savings. Aluminum forming is difficult to apply to mass-production techniques. Argonne has been working to improve forming technologies, along with related lubrication studies, for aluminum metal sheet. Argonne has also been examining fastening technologies, including welding, that must be modified when using aluminum instead of steel.

\section{Status}

The focus of the Ford vehicle field assessment is on fuel consumption, but other operational characteristics peculiar to aluminum-body vehicles will also be observed and documented. Researchers will note any corrosion or other surface/ paint problems, as well as any tendency to dent or suffer surface damage.

The assessment is being done under realistic operational conditions. Chassis cynamometer tests following the federal urban and highway cycles, as well as other proposed cycles, are being conducted to establish a controlled baseline.

\section{Future Plans}

Argonne is investigating alternative means to achieve mass reduction without downsizing passenger and cargo space. Novel structural concepts and the use of unconventional materials and forms are being examined.

Additionally, Argonne is investigating new lubricants for aluminum sheet forming, which could result is very significant increases in die life and possible increases in the drawing capability of aluminum.

\section{Contacts}

For technical information, contact Frank Stodolsky, Center for Transportation Research, Energy Systems Division, Argonne National Laboratory, Suite 6000, 955 L'Enfant Plaza North, SW, Washington, D.C. 20024-2168. Phone: 202/488-2431; Fax: 202/488-2444.

For information on working with Argonne, contact the Industrial Technology Development Center, Argonne National Laboratory, 9700 South Cass Avenue, Argonne, Illinois 60439. Phone: (800) 627-2596; Fax: 708/252-5230.

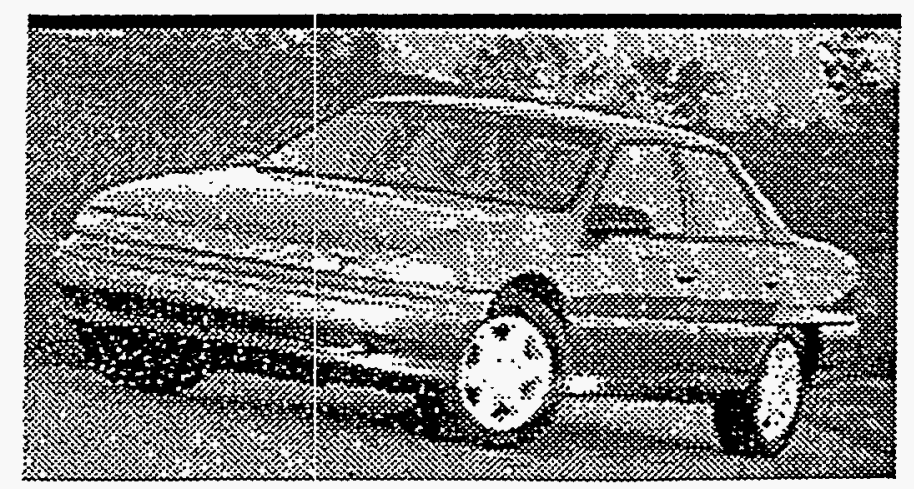

Argonne National Laborotory is assessing the fuel consumption and other operational characteristics of this aluminum-intensive Mercury Sable from Ford Motor Co. 


\title{
Laser-Based Inspection Techniques Characterize Ceramic Surfaces
}

\author{
Argonne is exploring the use of loser-based methods for rapid detection and \\ quantification of surface and subsurface defects in silicon nitride ceramics.
}

\section{Opportunity}

Silicon nitride $\left(\mathrm{Si}_{3} \mathrm{~N}_{4}\right)$ is currently the primary material of choice for replacing metals in many structural applications because of its mechanical and thermal properties. The lifetimes of these ceramic components are most affected by defects such as voids, inclusions, or microstructural variations in the surface or immediate subsurface $(<200 \mu \mathrm{m})$ region. Thus, a technique for rapid detection and quantification of both surface and subsurface defects is needed.

\section{Argonne Approach}

Argonne National Laboratory is exploring laser-based inspection techniques for characterizing machined or life-cycled ceramic surfaces, with an emphasis on silicon nitride ceramics.

\section{Technical Concept}

Traditional surface inspection uses contact techniques, is generally time-consuming, and is only sensitive to surface variations. Because the smallest critical defects are located on or just beneath the surface, several methods of nondestructive evaluation (NDE) such as radiography (including high-resolution X-ray (T) and ultrasonics are also not wellsuited for defect detection. However, since $\mathrm{Si}_{3} \mathrm{~N}_{4}$ can partially transmit visible light, Argonne has applied laser scattering to the analysis of various $\mathrm{Si}_{3} \mathrm{~N}_{4}$ materials fabricated into several component shapes. Using polarization techniques to independently analyze surface and subsurface material, Argonne scientists have detected simulated defects as deep as $200 \mu \mathrm{m}$ or more below the surface. Thus, laser-based methods provide the added benefit over traditional techniques of being multidimensional, in that they have the potential to simultaneously provide information on the machined surface texture and orientation, the presence of surface or near-subsurface flaws, and the extent of subsurface microcracking induced by the machining or life-cycling process.

\section{Advantages}

Combining this technology with computer-controlled acquisition and analysis permits on-line, real-time characterization of machined ceramic surfaces. This avoids the continued machining of a defective part and allows detection of damage that has been introduced by the machining tool. In addition, such a method may also prove advantageous in analyzing life-cycled components to identify the onset of subcritical damage to prevent component failure.

\section{Contacts}

For technical information, contact William Ellingson, Instrumentation and NDE Section, Energy Technology Division, Argonne National Laboratory, 9700 South Cass Avenue, Chicago, Illinois 60439. Phone: (708) 252-5068; Fax: (708) 252-4798.

For information on working with Argonne, contact the Industrial Technology Development Center, 9700 South Cass Avenue, Chicago, Argonne, Illinois 60439. Phone: (800) 627-2596; Fax: (708) 252-5230.

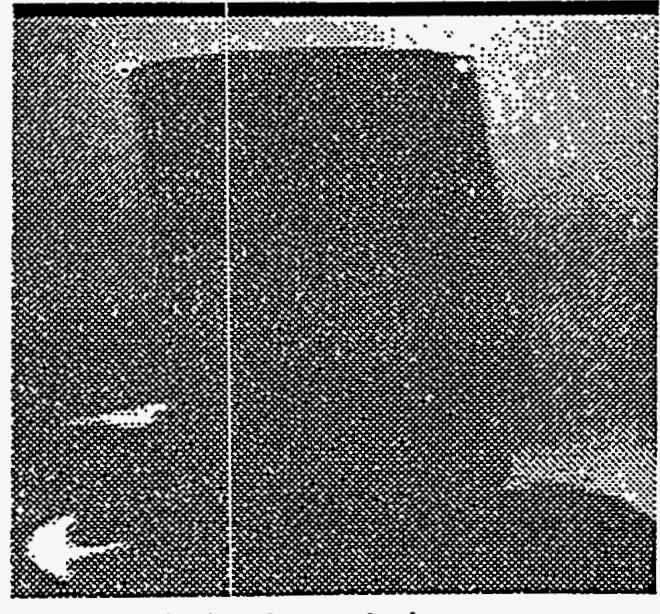

Photograph showing optical penetrotion through a $0.8 \mathrm{~mm}$ thick region of a Sis $\mathrm{N}_{4}$ turbine blade. 


\title{
Recovering Plastics from Scrapped Autos
}

\author{
Metals in scrapped cars are being recycled-why not plastics? \\ Recycling plastics could reduce landfill wastes by $25 \%$.
}

\section{Opportunity}

Auto shredders generate 3 to 5 million tons of waste, commonly known as automotive shredder residue (ASR), annually. Recycling automotive plastics, which constitute about $20 \%$ to $30 \%$ of ASR by weight, is not currently practiced on a commercial basis. Reasons are lack of a cost-effective technology for recovering plastics, potential contamination of the plastics with other materials from the ASR stream, and the absence of a strong market.

\section{Argonne Solution}

All that may change. Argonne National Laboratory is testing a technically promising, potentially economical process to recycle polymers from ASR. Recovered plastics could be used to make carpet padding, PVC piping, furniture, garbage cans, and automobile parts.

\section{Advantages}

If commercialized, the Argonne process could reduce by about $25 \%$ the amount of ASR going to landfills. The value of the recovered plastics could be very competitive in a variety of applications: One of the first might be polyurcthane foam for carpet padding. Because other recovered plastics are compatible with virgin plastics, they can be used for a variety of products.

\section{Technical Concept}

The Argonne technique for recycling ASR begins with mechanical/physical separation of the ASR into several fractions: polyurethane foam, which is separated and cleaned; iron-oxide-rich "fines," which may be used by the cement industry as a source of iron oxide; and a plastics-rich stream, from which Argonne dissolves and recovers heatformed plastics (thermoplastics). The solvent used in the process is regenerated and continuously recycled. If fines and plastics are recycled, as much as $75 \%$ of landfill waste could be eliminated.

\section{Status}

A demonstration plant at a shredder site is now processing polyurethane foam. At the same time, four different plastics are being recovered in a batch-process unit, in quantities of 1 to 5 pounds each. The plastics being recovered for evaluation are acrylonitrile-butadiene-styrene, polyvinyl chloride, polyethylene, and polypropylene.

\section{Future Plans}

Some 20,000 pounds of polyurethane foam is being accumulated for an Argonne techno-economic evaluation in early 1995. Argonne engineers are designing a continuous-process demonstration plant that could produce 3,000 tons of foam per year. Commercialization of the polyurethane foam process could come as early as the end of 1995 or the beginning of 1996.

\section{Contacts}

For technical information, contact Bassam Jody, Energy Systems Division, Argonne National Laboratory, 9700 South Cass Avenue, Argonne, Illinois 60439. Phone: 708/252-4206; Fax: 708/252-3443.

For information on working with Argonne, contact the Industrial Technology Development Center, Argonne National Laboratory, 9700 South Cass Avenue, Argonne, Illinois 60439. Phone: (800) 627-2596; Fax: 708/2525230. 


\title{
Reducing Emissions by Applying Oxygen-Enrichment Technology to Internal Combustion Engines
}

\author{
Argonne National Laboratory's initial studies of diesel engines using oxygen-enrichment technology \\ showed about a 50\% improvement in engine power density potential, a 5\% improvement in \\ thermal efficiency, and virtual elimination of smoke and particulate emissions.
}

\section{Opportunity}

Although researchers have known about the oxygenenrichment concept for nearly two decades, a practical means of supplying oxygen-enriched air to vehicle engines only became available in the mid-1980s. Membrane separators, which split the air flow into oxygenrich and nitrogen-rich streams, are now commercially available. The nitrogen-rich air stream is used by process industries for food storage and chemical reaction blanketing. What is still needed is a membrane to provide oxygen-enriched air for enhanced engine combustion.

\section{Argonne Solution}

Since 1989, Argonne National Laboratory has used oxygen-enriched combustion air to enhance engine performance and reduce exhaust emissions. Argonne is now studying oxygen-enrichment technology for alternative-fueled passenger vehicles and diesel locomotives. Researchers are using a permeable membrane to separate air into oxygen- and nitrogen-enriched streams. Integral to this research is development of devices to control nitrogen oxides $\left(\mathrm{NO}_{\mathrm{x}}\right)$ emissions.

\section{Advantages}

Argonne's tests on a production passenger car using oxygen-enriched combustion air showed remarkable reductions in hydrocarbon and carbon monoxide (CO) emissions, especially in the cold-start phase.

In addition, emissions of the four major air toxicsformaldehyde, acetaldehyde, benzene, and 1,3-butadiene-were dramatically reduced.

\section{Technical Concept}

While Argonne decreased hydrocarbon and $\mathrm{CO}$ emissions in both diesel- and gasoline-engine tests, $\mathrm{NO}_{x}$ emissions increased significantly. However, $\mathrm{NO}_{x}$ reduction can be addressed through focused aftertreatment because only one component of the exhaust gas needs to be decreased. In response to this challenge, Argonne researchers have devised a synergistic solution. After the permeable membrane separates air into oxygen- and nitrogen-enriched streams, the oxygen-rich stream is fed into the intake for enhanced combustion, while the nitrogen-rich stream is merged with the exhaust to reduce $\mathrm{NO}_{x}$ emissions. As an added benefit, oxygen-enriched combustion increases power without requiring an increase in engine size.

\section{Status}

The results from laboratory experiments to date are encouraging for reducing emissions in engines used in transportation applications. Early studies conducted on diesel engines showed about a 50\% improvement in engine power density potential, a 5\% improvement in thermal efficiency, and virtual elimination of smoke and particulate emissions.

\section{Contacts}

For technical information, contact Raj Sekar, Center for Transportation Research, Energy Systems Division, Argonne National Laboratory, 9700 South Cass Avenue, Argonne, Illinois 60439. Phone: (708) 252-5101; Fax: (708) 252-3443.

For information on working with Argonne, contact the Industrial Technology Development Center, Argonne National Laboratory, 9700 South Cass Avenue, Argonne, Illinois 60439. Phone: (800) 627-2596; Fax: (708) 252-5230.

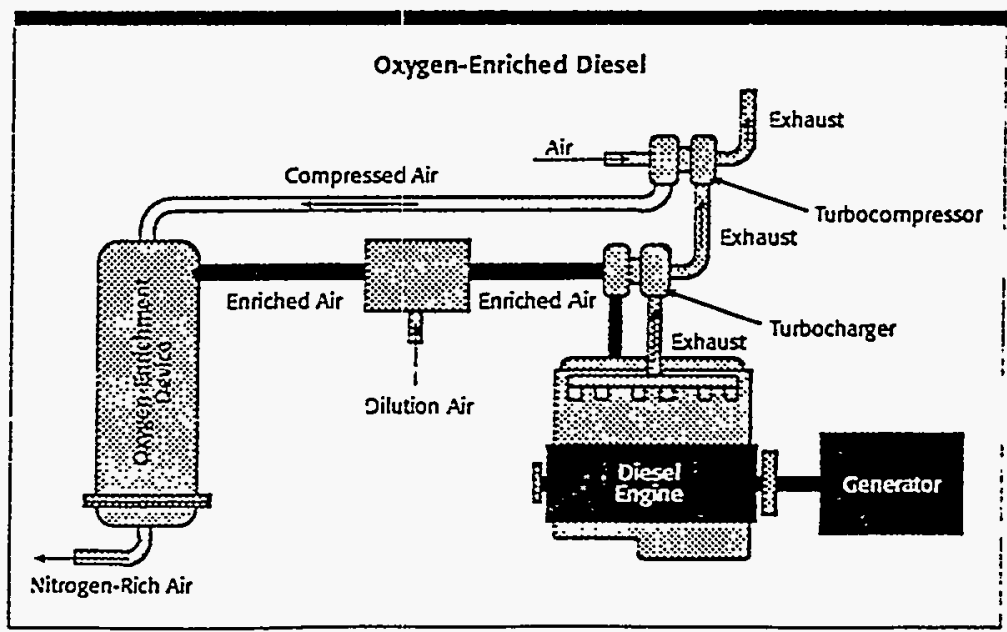




\title{
Polymer-Electrolyte Fuel Cells for Transportation
}

\author{
Fuel cells are strong candidates to replace the internal combustion engine because they are energy-efficient, fuel- \\ flexible, and clean. With polymer electrolytes, useful power can be drawn at room temperatures.
}

\section{Opportunity}

Transportation accounts for approximately one-fourth of all energy consumed in the United States and two-thirds of U.S. petroleum use. As domestic oil production declines, more efficient power systems are needed for transportation vehicles, especially those that use alternative fuels. Meanwhile, the internal combustion engine is a major cause of urban air pollution. Developing fuel-cell power systems might resolve both problems.

Use of fucl cells could dramatically lower both petroleum consumption and "tailpipe emissions" if applied to transportation vehicles. Operating efficiencies in the 35\% to $50 \%$ range are expected for transportation applications, compared with about $20 \%$ for internal combustion engines. Because fuel cells operate far below the combustion temperature of an engine, a fuel-cell-powered vehicle would have near-zero emissions.

\section{Fuel Cell Technology}

Fuel cells are electromechanical devices that convert the energy of a chemical reaction directly into electricity. In a typical system, hydrogen and oxygen from air react to produce electricity, heat, and water. The hydrogen fuel may be in the form of a stored gas, or it may be processed from a hydrogen-rich fuel, such as natural gas, methanol, or coal.

\section{Argonne Approach}

Argonne National Laboratory is pursuing fuel-cell transportation R\&D along several technical paths. One approach is based on a fluorocarbon ion-exchange membrane as the electrolyte of the fuel cell. This type of membrane can carry higher current densities than electrolytes now in use.

\section{Advantages}

Using a solid polymer electrolyte instead of a liquid simplifies sealing and reduces corrosion. But the greatest advantage of the technology is its ability to operate at temperatures below $100^{\circ} \mathrm{C}$. Useful power can be drawn from the cell at room temperature, which means faster, easier start-ups.

\section{Technical Concept}

A drawback of the low operating temperature is the fuelcell's limited tolerance for carbon monoxide, a byproduct of hydrogen manufacture. Argonne is investigating alternative electrocatalysts that are less susceptible to fuel impurities.

\section{Status}

Using fundamental scientific principles and electrochemical characterization techniques, Argonne is exploring binary and ternary metal alloys as potential new catalysts.

\section{Future Plans}

Improved catalysts will be provided to fuel-cell manufacturers.

\section{Contacts}

For technical inforrnation, contact Michael Krumpelt, Chemical Technology Division, Argonne National Laboratory, 9700 South Cass Avenue, Argonne, Illinois 60439. Phone: 708/252-8520; Fax: 708/252-4176.

For information on working with Argonne, contact the Industrial Technology Development Center, Argonne National Laboratory, 9700 South Cass Avenue, Argonne, Illinois 60439. Phone: (800) 627-2596; Fax: 708/2525230. 


\title{
Solid-Oxide Fuel Cells for Transportation
}

\author{
Fuel cells are strong candidates to replace the internal combustion engine, but their size and weight \\ need to be reduced greatly before they are commercialized. Ceramic technology can help accomplish \\ this by eliminating the cumbersome external resormer.
}

\section{Opportunity}

Although the internal combustion engine-a mature technology, surely-has been under constant development for over 100 years, it is largely responsible for much of the air pollution associated with urban America. Clearly, in the face of declining domestic petroleum production and increased reliance on foreign energy resources, alternative fuels and unconventional power systems are high priorities for transportation research.

Fuel cells represent an important new technology to dramatically lower both petroleum use and "tailpipe emissions," if applied to transportation vehicles. Operating efficiencies in the 35\% to $50 \%$ range are expected for fuel cells, compared with about $20 \%$ for internal combustion engines. Because fuel cells operate far below the combustion temperature of an engine, fuel-cell-powered vehicles would have near-zero emissions.

\section{Fuel Cell Technology}

Fuel cells convert chemical energy directly into electricity. In a typical system, hydrogen and oxygen from air react to produce electricity, heat, and water. The hydrogen fuel may be in the form of a stored gas, or it may be processed (reformed) from such hydrogen-rich fuels as natural gas (methane), methanol, or coal.

\section{Argonne Approach}

Argonne National Laboratory is pursuing several paths in fuel-cell transportation R\&D. One approach is to develop a solid-oxide (ceramic) fuel cell. Because they operate at higher temperatures, solid-oxide fuel cells do not need platinum or other precious metals as catalysts. They are also much more tolerant of fuel impurities (e.g., carbon monoxide) than are lower temperature systems.

\section{Advantages}

A solid-oxide power system has relatively few components. Because the system comprises all-ceramic structures, solid-oxide fuel cells may need less maintenance and be less expensive than other fuel-cell approaches. Most important, the solid-oxide system needs no reformer to split off elemental hydrogen from the hydrogen-rich fuel. The necessary reforming is internal to the system. This means potentially large weight savings and a more compact system.

\section{Technical Concept}

Argonne is developing materials and fabrication methods for a ceramic fuel cell that would fit into a passenger car. The new materials will improve the power density of the fuel cell and allow rapid start-up.

\section{Status}

Development of this new solid-oxide fuel cell is still in the laboratory phase, but it may gain momentum under the Partnership for a New Generation Vehicle.

\section{Future Plans}

The next step in this development is building a prototype that is large enough for system demonstration.

\section{Contact}

For technical information, contact Michael Krumpelt, Chemical Technology Division, Argonne National Laboratory, 9700 South Cass Avenue, Argonne, Illinois 60439. Phone: 708/252-8520; Fax: 708/252-4176.

For information on working with Argonne, contact the Industrial Technology Development Center, Argonne National Laboratory, 9700 South Cass Avenue, Argonne, Illinois 60439. Phone: (800) 627-2596; Fax: 708/2525230 . 


\title{
Surface Acoustic Wave Chemical Sensors Accurately Monitor Emissions in R'eal-Time
}

\author{
Chemical sensors offer sensitivity, ruggedness, and compact size for environmental emissions monitoring.
}

\section{Opportunity}

Sensors that reliably monitor emissions and detect toxic chemicals can aid air-pollution measurements and industrial and automotive emissions monitoring.

\section{Argonne Approach}

Argonne National Laboratory is developing various surface acoustic wave (SAW) chemical sensors for environmental emissions monitoring and toxic chemicals detection. Researchers are studying thin-film technology, coating techniques, and surface chemistry. Artificial neural networks are being evaluated and applied to pattern recognition for sensing gas mixtures. Special coating materials for sensing radionuclides are also being assessed.

\section{Advantages}

Chemical sensors offer many attractive features for emissions monitoring, including sensitivity, ruggedness, and compact size. In addition, these sensors are relatively inexpensive and provide on-line, real-time, and inprocess monitoring.

\section{Technical Concept}

A surface acoustic wave chemical sensor consists of two arrays of interdigital transducers (ITD) deposited on a piezoelectric substrate, a ST-quartz or a lithium niobate crystal, and a chemical selective coating bonded on the surface between the ITDs. The sensing principle is based on the mass-loading effect on SAW propagation velocity. When a chemical under detection is absorbed by the coating, the SAW propagation velocity, and thus, the SAW frequency established between the two ITDs, will be altered. The amount of change in frequency or velocity gives a quantitative measure of the chemical. Because the frequency change is proportional to the square of the operating frequency and the chemical mass, a SAW sensor increases its detection sensitivity when the operating frequency is raised.

The selectivity of a SAW sensor depends on the application of the proper coating material. This has been demonstrated in detection of trace gases such as carbon monoxide (CO), methane, and $\mathrm{SO}_{x}$. The SAW sensor can be applied to gas mixture detections by using an array-sensor design coupled with pattern recognition algorithms.

\section{Status}

Argonne researchers are focusing on thin films that can sustain high-temperature environments and are chemically sensitive to the targeted gases, including $\mathrm{NO}_{x}, \mathrm{CO}$, carbon dioxide, and hydrocarbons. In the initial phase of the program, researchers will work on the basic configuration of a SAW chemical sensor and the basic design of a flexural-plate-wave chemical sensor. (See figures.)

\section{Contacts}

For technical information, Shuh-Haw Sheen, Energy Technology Division, Argonne National Laboratory, 9700 South Cass Avenue, Argonne, Illinois 60439. Phone: (708) 252-7502; Fax: (708) 252-3250.

For information on working with Argonne, the Industrial Technology Development Center, Argonne National Laboratory, 9700 South Cass Avenue, Argonne, Illinois 60439. Phone: (800) 627-2596; Fax: (708) 252-5230.

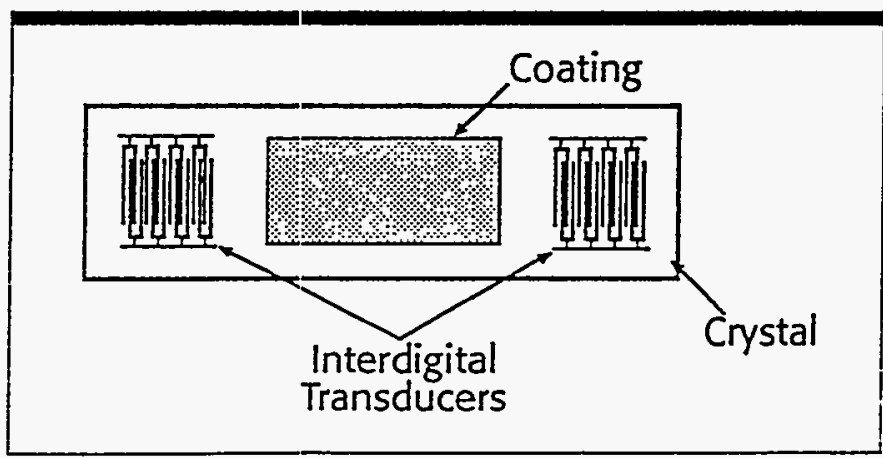

Figure 1: The basic configuration of a surface-acoustic-wave chemical sensor.

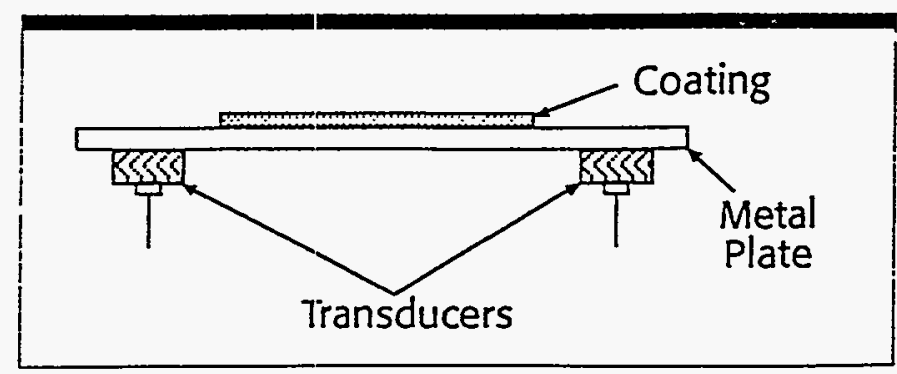

Figure 2: The basic design of a flexural-plate-wave chemical sensor. 


\title{
Argonne Plays a Leading Role in Parallel Computing Research
}

\author{
Advanced computing and communications and computational science and engineering are key components \\ in Argonne National Laboratory's research and development programs. Argonne's programs emphasize \\ the development and effective utilization of leading-edge computational capability. Particular emphasis is \\ given to parallel computing, high-speed communications, and sophisticated numerical algorithms. \\ These technologies are integrated into state-of-the-art engineering and scientific analysis computer codes \\ that undergo extensive, rigorous verification and volidation.
}

\section{Advanced Computing Facilities}

Argonne has long held a leading role in parallel computing research. Established in 1984, the Advanced Computing Research Facility recognized the growing importance of parallel computer architectures in scientific computing. Argonne's unique research infrastructure has included more than a dozen different parallel machine architectures. These architectures led to the development of an extensive set of software tools for program portability and application enablement that operate on an ever-widening range of parallel environments.

\section{Engineering Mechanics}

Argonne has developed a number of Engineering Mechanics computer codes to address issues such as fatigue and failure analysis, structural analysis, dynamics of complex mechanical systems, vibration analysis, crash worthiness, earthquake analysis and response, fluidstructure interactions, seismic isolation, and piping systems analysis. Some specific examples include the NEPTUNE code, a three-dimensional (3-D), finite element code capable of simulating problems that involve plate and/or shell structures, fluids, continua, fluid-structure interaction, media-structure interaction, contact mechanics, and silent boundaries. The TEMPSTRESS code improves the understanding of the behavior of concrete subjected to mechanical loadings and high temperatures. SISEC (Seismic Isolation System Evaluation Code) is a 3-D structural program for calculating the global response of isolated and unisolated structural systems, including the effect of soil-structure interaction. WHAMS3D is a nonlinear, finite element 3$D$ code for transient analysis of frames, shells, plates and continua. FLUSTR-ANL (Fluid Structure Interaction Code) is a general fluid-structure interaction analysis code.

\section{Computational Fluid Dynamics}

Argonne is exceptionally strong in applying computational fluid mechanics to the simulation of flows and heat transfer in complex components of advanced energy systems. For example, COMMIX, a general purpose, 3-D code, contains extensive modeling of turbulent transport, buoyancy effects, and flow stratification. The Casting Process Simulator (CaPS) is used to predict the flow and solidification of molten metals in complex casting operations.

FLUFIX-3D is a solution to general mass conservation equations and separate phase momentum equations for transient and isothermal fluid-solids nonreactive multiphase flow. SWAAM is a method of characteristics/ finite difference code for fluid transients, including cavitation and plastic pipe deformations.

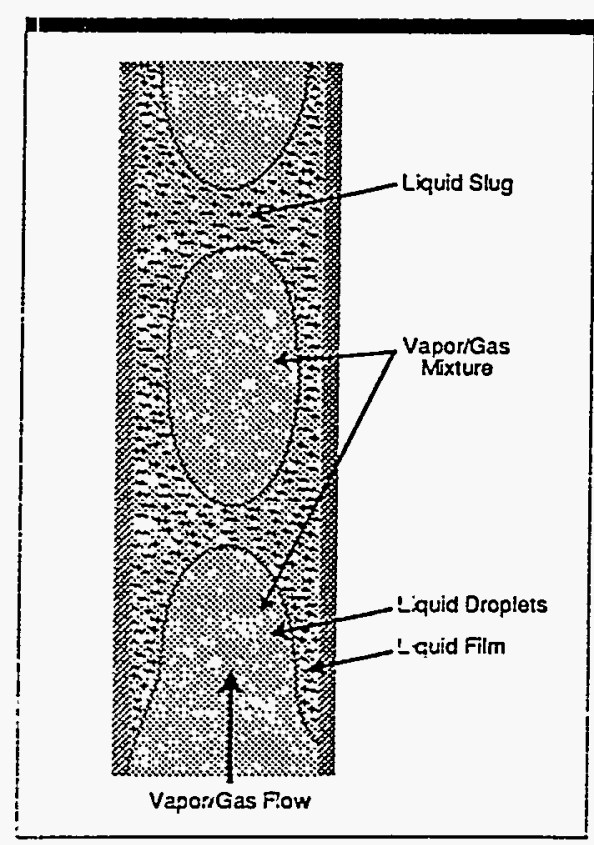

LEVITATE, a multiphose, multicomponent code, describes the flow through a pipe of a heavy liquid entrained in a vapor/gas mixture. The combination of local annular and bubbly flow allows complicated flow patterns, such as the one shown here, to be described. Argonne scientists expect that similar flow patterns play an important role in an engine-cooling system's performance during abnormal situations, such as overheating. 
Many of the problems associated with the design and analysis of engine systems include multiphase, multicomponent transient flows. For several years, Argonne scientists have used LEVTTATE, a multiphase, multicomponent code, to analyze the transient behavior of complicated thermal-hydraulic systems involving multicomponent flow with phase changes (solid, liquid, or gas). Automakers are considering the use of codes like LEVITATE to model and analyze fuel-injection and exhaust systems.

\section{System Stimulation}

Argonne has developed the GPS-General Purpose Simulation code. GPS models complex manufacturing systems assembled from component units to facilitate the design and evaluation of production processes. GPS models continuous and discrete event systems and supports rapid prototyping and systems analysis.

\section{Information Management \& Decisionmaking}

Several Argonne-developed tools for information management and decisionmaking are in use at at the Laboratory. These include AIE-APPLICATIONS INTERFACE ENGINE-an environment for rapid prototyping and full development. AIE supports workable user interfaces, provides transparent access to multiple sources of information and data, and helps designers make decisions by linking applications. PASS-PORTFOLIO ANAIYSIS SUPPORT SYSTEM-is a PC-based decision analysis tool that provides several levels of analysis capability for prioritizing projects and analyzing portfolios, although it can be used to analyze almost any set of alternatives. IDEA-INTERACTIVE DECISION ANALYSIS-is a PC-based decision support tool that evaluates decision problems characterized by alternative courses of action, uncertainty, and multiple conflicting objectives. RASS-RESOURCE ANALYSIS SUPPORT SYSTEM-is a PC-based decision-aiding system that assists in program and budget decisionmaking over a multiyear period.
Software Tools and Mathematical Software Argonne has developed a suite of mathematical software that can be used to optimize the performance of advanced computing systems for various applications. Specific examples include MINPACK-2, a project to produce optimization algorithms and software for highperformance computers; ADIFOR (Automatic Differentiation of Fortran), a Fortran source translator that augments Fortran 77 programs with derivative computations, for example, for design optimization and sensitivity analysis; OTTER, an automated deduction system designed to prove theorems stated in first-order logic with equality; BlockSolve, a scalable parallel software library for the solution of large sparse, symmetric systems of linear equations; P4, a third-generation system for portable programming or parallel machines in $\mathrm{C}$ and Fortran. PCN is a parallel programming system designed to improve the productivity of scientists and engineers using parallel computers; PETSc, a large tool kit of software for portable, parallel (and serial) scientific computation.

\section{Contacts}

For technical information, contact Thomas Morgan, Mathematics and Computer Science, Argonne National Laboratory, 9700 South Cass Avenue, Chicago, Illinois 60439. Phone: (708) 252-5218; Fax: (708) 252-5986.

For information on working with Argonne, contact the Industrial Technology Development Center, 9700 South Cass Avenue, Argorne, Illinois 60439. Phone: (800) 627-2596; Fax: (708) 252-5230. 


\title{
Flywheel Provides Efficient Energy' Storage
}

\author{
A flywheel energy storage system can cut costs, save energy, reduce pollution, \\ and minimize the need for new power plants.
}

\section{Opportunity}

New research could result in this highly efficient energystorage device, significantly changing the way energy is produced and supplied.

\section{Argonne Approach}

Researchers from Argonne National Laboratory and Chicago's Commonwealth Edison utility have scored a major breakthrough in the age-old battle against friction, setting a world record for the least friction created in a magnetic bearing. Friction is the force that robs engines and other machinery of their power and efficiency.

The jointly developed bearing has ten times less friction than its closest competitor. The bearing is the essential component of a highly efficient flywheel energy-storage dcvice that economically stores and releases energy.

\section{Advantages}

Flywheels enable load leveling in electrical generation or industrial applications. Coupled to a suitable electric motor/generator, utilities and other heavy users of electrical power can balance the peaks in electrical demand by using flywheels to alternately store and release needed electricity.

In an electric vehicle, flywheel energy storage can be used with regenerative braking. By feeding power back into the motor/generator attached to the flywheel, the vehicle's braking energy is converted into energy in the flywheel instead of being wasted. In addition, one or more on-board flywheels in a vehicle could be spun up during off-peak electrical generation periods, storing energy for later use.

\section{Technical Concept}

To store a large amount of energy, the flywheel must spin at high rotational speeds. These speeds are achieved most reliably with flywheels made of high-strength, graphite fiber materials. Argonne scientists are working with academic researchers to examine the use of fiberwound composite rotors, which can be spun at much higher speeds than conventional metal rotors.
Any practical flywheel must be supported on very lowfriction bearings to avoid energy loss. The Argonne/ Commonwealth Edison bearing uses a permanent magnet trapped and suspended in a magnetic field above an array of high-temperature superconductors-materials that lose all electrical resistance when cooled by liquid nitrogen. The magrietic bearing supports the flywheel as it moves at 1,100 yards (1,000 meters) per second-about three times faster than the speed of sound. Part of the bearing is attached to the bottom half of the flywheel.

The bearing's other half is an Argonne-made hightemperature superconductor. When the superconductor is cooled to minus 321 degrees Fahrenheit, it generates a magnetic field that causes the magnet/flywheel assembly to float above the superconductor. The two surfaces never touch.

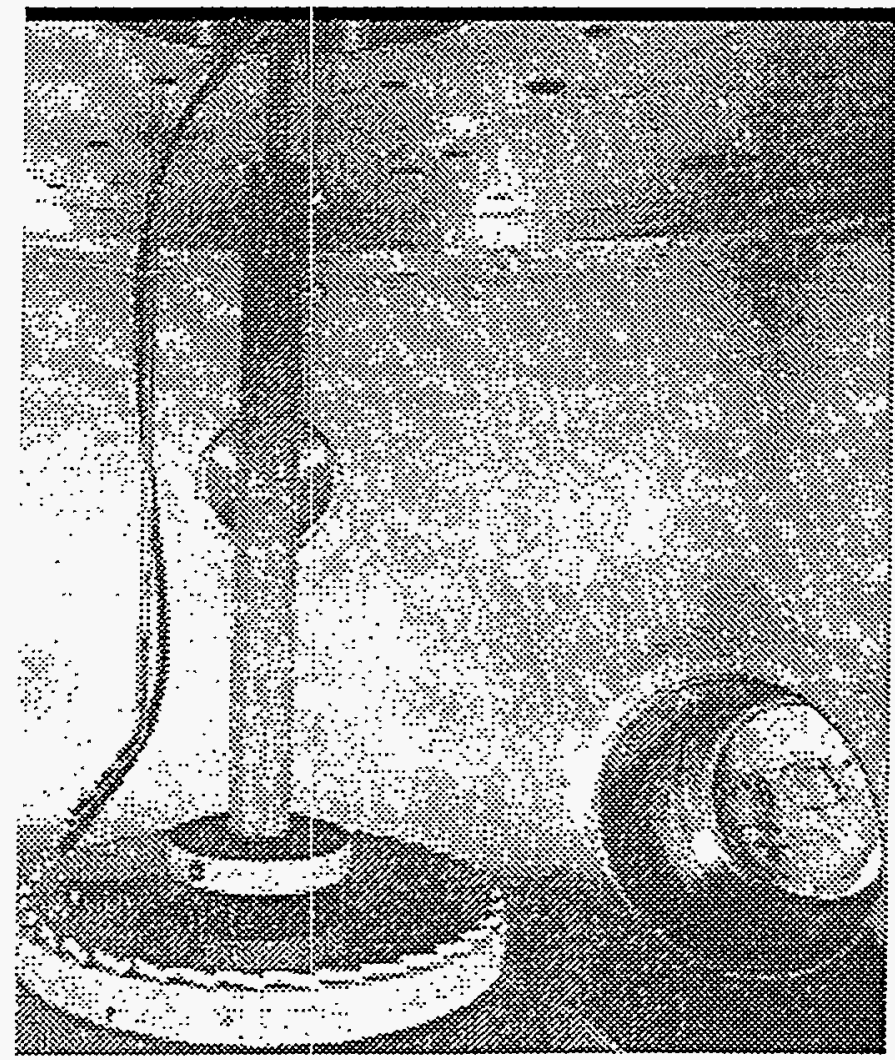

Highly efficient flywheel energy storage systems, such as the one shown here, could revolutionize the way energy is produced and supplied to consumers. 


\section{Status}

A vacuum chamber called the Flywheel Energy Storage Test Apparatus permits many different system configurations and operating conditions to be tested. A motor/ generator unit is being designed to work with this test chamber to demonstrate efficient power input/output. Researchers are still determining the best method to transfer energy in and out of the flywheel.

Tests are presently being conducted on a 15-inch (38centimeter) flywheel that weighs 27 pounds (12 kilograms). These flywheels are expected to store one to two kilowatt-hours, or enough to power ten 100-watt light bulbs for two to five hours. Researchers are developing a commercial product that eventually will wcigh up to 40 tons and store five megawatt-hours of electricity.

\section{Future Plans}

Researchers are continuing magnetic bearing and flywheel energy storage system development. A field test of a $50 \mathrm{~kW}$-hr energy storage unit is planned for 1995.

\section{Contacts}

For technical information, contact John Hull, Superconductivity Applications Section, Energy Technology Division, Argonne National Laboratory, 9700 South Cass Avenue, Argonne, lllinois 60439. Phone: (708) 2528580; Fax: (708) 252-5568.

For information on working with Argonne, contact the Industrial Technology Development Center, Argonne National Laboratory, 9700 South Cass Avenue, Argonne, Illinois 60439. Phone: (800) 627-2596; Fax: (708) 2525230 . 


\title{
Collaborative R\&D in Laser Applications Laboratory Helps Advance Materials Processing in Automotive Manufacturing
}

\author{
Argonne/industry partnerships positively impact the viability and cost-effoctiveness \\ of processing technology in this application.
}

\section{Opportunity}

Improvements in laser-beam delivery, power measurement, and sensors for on-line process monitoring can advance the high-power laser processing technology currently used in automotive manufacturing.

\section{Argonne Approach \\ Argonne National Laboratory's Laser Applications Laboratory (LAL) conducts research and development on laser-based applications for materials processing and acrosol and spray characterization. Collaborative re- search and development activities (CRADAs) with industrial partners is a key activity.}

\section{R\&D Goals}

In general, Argonne plans to develop an engineering design database that will facilitate the use of lasers in materials processing functions. More specialized goals include development and optimization of laser processing technology suitable for specific operations on the production floor.

\section{Equipment and Capabilities}

The LAL facility houses two, high-power industrial laser systems, complete with diagnostic instrumentation for materials processing functions: a $6-\mathrm{kW}$ carbon dioxide $\left(\mathrm{CO}_{2}\right)$ laser and a 1.6-kW neodymium:yttrium-aluminum-garnet (Nd:YAG) laser. The equipment was provided by a $\$ 1.7$ million grant from the State of Illinois for Argonne and industrial partners to develop advanced material processing methods. The capabilities include cladding, cutting, drilling, heat treating, welding, and laser thermal simulation studies.

Several low-power lasers, including visible to nearinfrared diode lasers, nitrogen and dye lasers, and helium-neon lasers are used for characterizing and controlling aerosols and sprays relevant to environmental control and fuel-injection optimization.

\section{Advantages}

Heat treating with lasers allows selective surface hardening against wear with little or no distortion of the component. Because this eliminates much part reworking that is currently done, the laser system's capital cost is recovered in a short time. An inert absorbent coating for laser heat treating has also been developed that eliminates the fumes generated by conventional paint coatings during the heat-treating process.

High-speed laser welding is a cost-effective alternative to conventional arc vrelding.techniques for joining automotive components. The significantly faster production speeds can overcome the higher capital cost of laser systems compared to MIG or TIG. Laser-blank welding can increase the structural integrity of the auto body and reduce its weight.

The laser-beam delivery system controls the intensity and power delivered to the workpiece. Improvements in beam shaping and control translate into better coupling of the laser-beam energy to the workpiece. This results in more efficient and faster processing. The LAL is working with a beam delivery supplier and a laser manufacturer to develop improved processing tools that use lasers for more cost-effective manufacturing.

Many systems for on-line monitoring of quality control have performed well in a laboratory environment but have failed on the production floor. Complexity, susceptibility to the environment, and cost have been the major causes of failure. The LAL has developed a prototype of a simple, rugged, and low-cost process monitoring sensor for laser welding. A. collaborative project with the automobile industry is under way to demonstrate the monitoring system's effectiveness on the factory floor.

\section{Status}

Argonne's LAL CRADAs are structured to be synergistic and complementary. Current CRADAs with industrial partners include:

- Optimization of laser-beam heat treating (Caterpillar);

- High-speed laser welding of stainless steels for automobile exhaust systems ( $A C$ Rochester);

- Optimization of laser-beam delivery system and power meter (Spazor Industries); 
- On-line process monitoring for laser-beam welding (USCAR);

- Fiber-optic beam delivery for high-power Nd:YAG lasers (U.S. Laser); and

- Optimization of laser cutting parameters for textiles (AMTEX).

\section{Contacts}

For technical information, contact Keng $\mathrm{H}$. Leong, Laser Applications Laboratory, Technology Development Division, Argonne National Laboratory, 9700 South Cass, Argonne, Illinois 60439. Phone: (708) 252-3254; Fax: (708) 252-4007.

For information on working with Argonne, contact the Industrial Technology Development Center, Argonne National Laboratory, 9700 South Cass Avenue, Argonne, Illinois 60439. Phone: (800) 627-2596; Fax: (708) 2525230. 


\section{Analyses and Diagnostics Laboratory Fosters Advanced Battery Systems for Electric Vehicles}

\section{Opportunity}

An elcctric vehicle's battery weight limits its range and payload. Current technology is best suited for a range of under 50 miles between battery chargings. A partnership involving America's "Big Three" automobile manufacturcrs (General Motors, Ford, and Chrysler), the Electric Power Research Institute, and the U.S. Department of Energy (DOE) was created to accelerate development of advanced battery systems for electric vehicles. Created in 1991 , this partnership was named the U.S. Advanced Battery Consortium (USABC).

\section{Advantages of Battery R\&D}

Advances that increase range and decrease battery weight will improve the operational performance of electric vehicles.

\section{Primary Goals and Objectives}

To achieve such advances, Argonne National Laboratory is working with the USABC and industry battery developers to form battery $R \& D$ teams and to define the work to be performed by Argonne and each of the industrial partners. Argonne's Analysis and Diagnostics Laboratory (ADL), established by DOE in 1976, is being used to study advanced battery systems. Advanced battery candidates are being evaluated to quantify their performance and life characteristics, assess their developmental status, and identify their operational limits and deficiencies for electric vehicle applications.

\section{Facility Description}

Argonne's ADL houses two laboratories: a versatile computer-operated test laboratory and a post-test analysis laboratory. In the test laboratory, researchers subject cells, multicell modules, and full-size battery systems fabricated by industrial firms to performance and lifetime testing that simulates electric vehicle applications. Then, in the post-test laboratory, researchers analyze failed cells (in a protected atmosphere, if needed) to assess component reliability and correlate operational performance with material changes.
In this facility, researchers apply unbiased tests and analyses, thereby creating a common basis for evaluating battery performance and life. For example, the information gained from the performance and lifetime tests, together with the post-test evaluations, provides benchmarks of technical progress. More importantly, scientists can identify specific changes in design or construction materials that could lead to improved battery performance.

\section{Staff Expertise and Experience}

During its 18 ycars of operation, researchers associated with the ADL have acquired considerable expertise in the technology and methodology of measurement and control of battcry test conditions. The ADL presently has more than 50 person-years of battery testing and analyses experience in projects for both the government and private industry. This expertise, along with the versatility of the ADL test system, has allowed a variety of units to be evaluated and analyzed. These range from small, individual cells to large battery systems. Also of interest have been electrolyte flow and high-temperature systems.

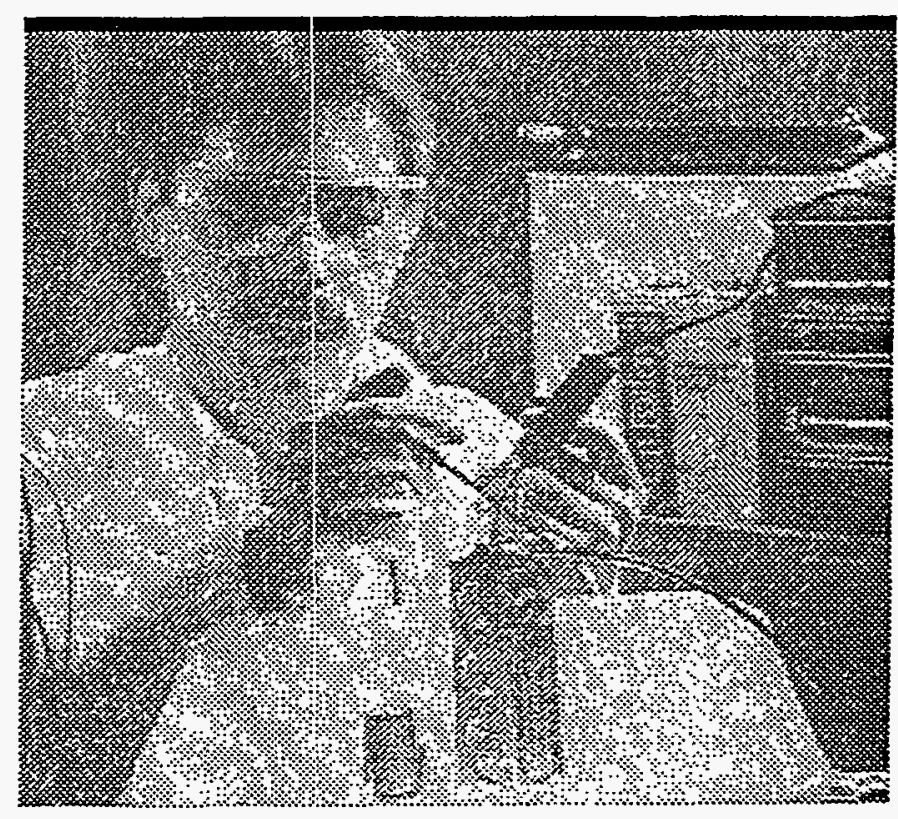

An Argonne researcher measures the voltage on a test battery. 


\section{Results and Accomplishments}

An excellent relationship has been established between the ADL and battery developers, manufacturers, and sponsors. More than 4,000 cells, ranging from individual 4-Wh cells to $22-\mathrm{kWh}$ batteries, have undergone performance and lifetime evaluations for electric vehicle, utility load-leveling, and standby power applications. These evaluations covered more than 12 technologies from more than 18 battery developers. The following are among the more significant contributions made in the areas of battery development, testing, and application:

- Different sizes and types of battery systems can now be compared on an equivalent basis because of data normalization techniques developed at the ADL;

- Batteries can now be evaluated more economically because the ADL demonstrated that electric vehicle range projections based on laboratory test data can accurately predict the ranges measured in vehicle tests; and

- $\quad$ R\&D needs have now been better defined as a result of identifying component failure mode and reliability issues and demonstrating that battery power losses are predictable when based on battery internal resistance and heating.

\section{Contacts}

For technical information, contact Kevin Michael Myles, Electrochemical Technology Program, Chemical Technology Division, Argonne National Laboratory, 9700 South Cass Avenue, Argonne, Illinois 60439. Phone: (708) 252-4329; Fiax: (708) 252-5528.

For information on working with Argonne, contact the Industrial Technology Development Center, Argonne National Laboratory, 9700 South Cass Avenue, Argonne, Illinois 60439. Phone: (800) 627-2596; Fax: (708) 252-5230. 


\section{DOE/Industry Competitions Advance Alternative-Fueled Automotive Technologies}

Since 1987, the U.S. Department of Energy (DOE) has sponsored 21 different college and high school engineering compctitions through Argonne National Laboratory that give students the opportunity to design and build a wide range of alternative-fucled vehicles. Approximately 5,400 students have benefited from the program since its inception. In 1993, more than 2,000 students took part in building approximately 100 competition vehicles. DOE's investment has been under $\$ 750,000$, and the cost per student for six to nine months of hands-on enginecring experience has been less than $\$ 350$.

DOE's objectives in funding the student vehicle competitions arc as follows:

\section{Technical Objectives}

- Advance the state of the art in fuel systems and powertrains and document student designs and vehicle accomplishments.

- Support innovations and ongoing research resulting from involvement in these competitions. Examples include:

- Northwestern University developed a gas quality sensor, OId Dominion University developed a gaseous fuel injector, and other teams developed several complex emissioncontrol systems.

- Four universities were awarded \$1.1 million in research grants on the basis of their competition experience.

- Three university hybrid-electric vehicles were used to help validate the draft Society of Automotive Engineers Hybrid-Electric Vehicle Emissions Procedures.

- At least eight student design documents and five nonstudent design documents have been published.

\section{Educational Objectives}

- Incrcase students' engineering knowledge through work on "real world" problems outside of the classroom.

- Provide students with hands-on experience, which often results in opportunities for automotive industry employment.
- Excite students about careers in science. The high school events have intercsted many students in science carcers.

- Inform and cducate the public about a!ternativefuc: techno'ogies.

\section{Institutional Objective}

Obtain industry participation to improve the relationship between DOE and industry, orher government agencies, the Socicty of Automotive Engincers International, and academia.

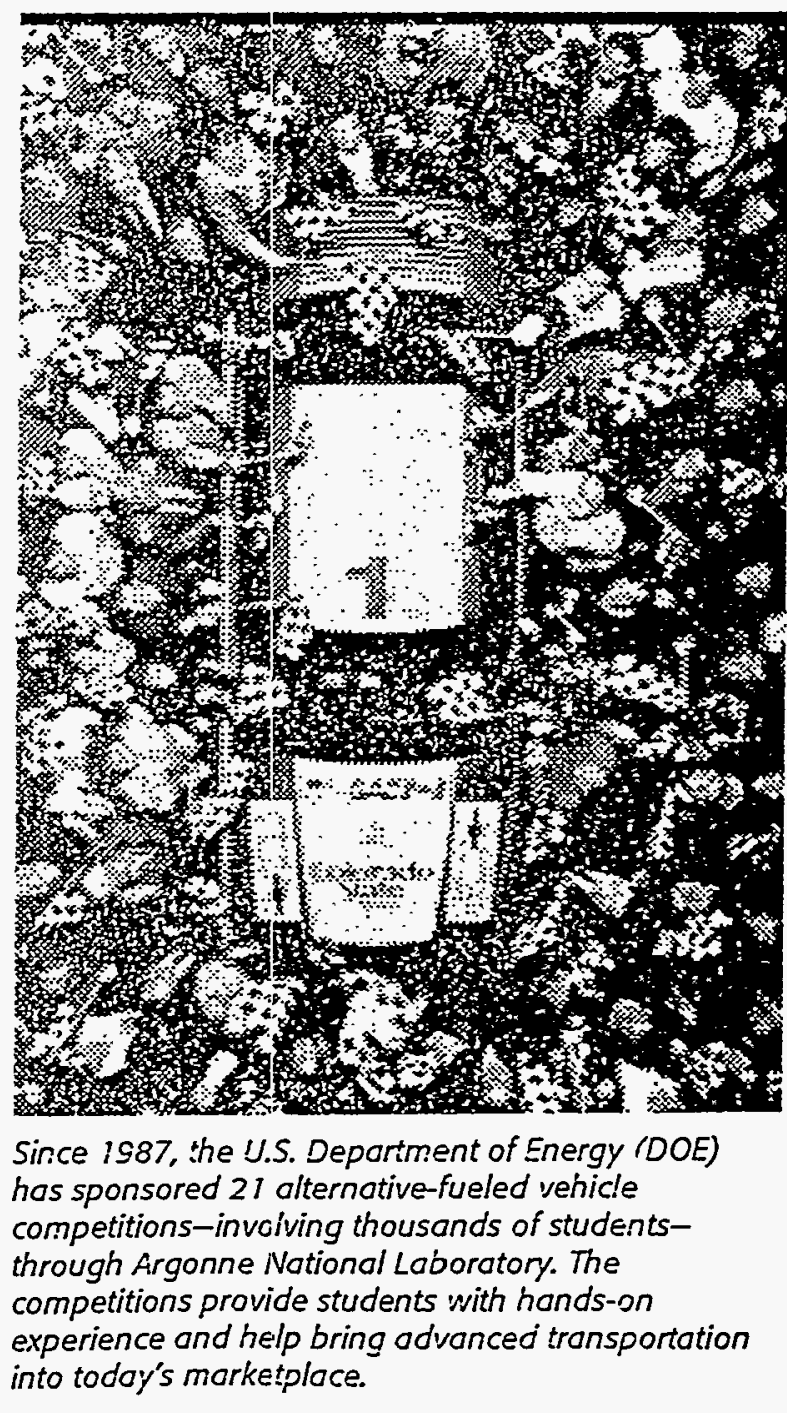




\section{Safety Objective}

Maintain the competitions' impressive safety record.

\section{Hybrid Electric Vehicle (HEV) Challenge}

The HEV Challenge is cosponsored by DOE, Chrysler Corp., and Natural Rcsources-Canada. Thirty-five colleges and universities from across North America will compete June 5-13 in Auburn Hills, Michigan. The competition challenges teams to meet stringent safety requirements, as well as the performance demands of today's vehicles. Based on near-term technology, the hybrid-electric prototype vehicles draw on the creativity of future automotive enginecrs to meet these challenges. Emissions, acceleration, encrgy economy, range, HVAC, and vehicle handling events are combincd with a review of the enginecring design work, technical reports, and consumer acceptability to determine the winning vehicle. For more information, contact Nicole LeBlanc at (708) 252-6594.

\section{DOE's Advanced Student Hybrid (DASH) Challenge}

DOE sponsors a competition for hybrid-electric vehicles built from the ground up. These hybrids competed in the 1993 and 1994 HEV Challenge competitions with great success. Eleven college and university vehicles will compete in a competition similar to the $1995 \mathrm{HEV}$ Challenge, scheduled to take place March 27-April 1 in Los Angeles, California. The California Air Resources Board will test the emissions of the hybrids. The DASH contact is Spencer Quong at (708) 252-6489.

\section{American Tour de Sol}

Now in its seventh year, the American Tour de Sol runs from Waterbury, Connecticut, to Portland, Maine (May 20-27). Intended to communicate the capabilities of electric vehicles to the general public and press, the rally focuses on efficiency and driving range. For more information, contact Nancy Hazard at (413) 774-6051.

\section{DOE's Clean Air Road Rally (CARR)}

The two-day DOE Clean Air Road Rally (DOECARR) is a shortened version of the American Tour de Sol competition, focusing on efficiency and range. DOECARR will be held in the Los Angeles area (March 31-April 1). All alternative-fueled vehicles are welcome to participate in this event. For further information, contact George Ettenheim at (602) 774-8474.

\section{High School Electric Vehicle Competitions}

Two high school electric vehicle competitions are sponsored in part by DOE. The APS Electric 500 and the Richmond EV Grand Prix provide teams of high school students with the opportunity to learn more about alternative-fueled vehicles. The teams convert gasolinefueled vehicles to electric power and compete in range, acceleration, and energy-efficiency events, as well as an engineering design review. The APS Electric 500 will be held at Firebird International Raceway (March 3-5). The Richmond EV Grand Prix will take place at the Richmond International Raceway (May 5-7). For additional information, contact Don Karner at (602) 978-1373.

\section{SAE Student Competitions}

DOE has sponsored the Alcohol Classes in the Formula SAE, as well as in the West Coast and Midwest Supermileage competitions, since 1987. More than 70 schools participated in the Formula SAE; 14 of these schools competed in the Methanol Class in 1994. These competitions concentrate on teaching the students about alcohol fuel properties, basic engine conversion requirements, and the advantages of alcohol-based fuels. The 1995 Formula SAE will be held May 18-21 at the Pontiac Silverdome, Michigan, while this year's West Coast Supermileage will take place June 10-11 in Sacramento, California. For further information, contact Bob Sechler at (412) $776-4841$. 


\title{
Diamond and Diamondlike-Carbon Coatings Provide Strength, Corrosion Resistance
}

\author{
Applied to piston rings/bores, such coatings can decrease syear and oil consumption; \\ as gear and bearing coatings, they can increase durability and load ccpccity.
}

\section{Opportunity}

Recent progress in low-pressure diamond synthesis has led to heightened interest in carbon coatings. In fact, Science magazine elected the diamond as the "Molecule of the Year," because the hardness and room-temperature thermal conductivity of a diamond is superior to that of any other substance known. "Diamondlike carbon" is a glassy material that can be almost as hard as diamond, is corrosion-rcsistant, and provides remarkably low friction.

\section{Argonne Approach}

Argonne National Laboratory is developing methods for producing crystalline cubic diamond coatings, as well as various types of amorphous carbon coatings. Considerable progress has been made in understanding the electronic, optical, and microstructural properties of diamond and diamondlike-carbon (DLC) films. Results of engineering testing are also beginning to emerge.

Several different types of hard carbon can be produced as thin coatings. Cubic diamonds with $s p^{3}$ bonding can be produced by plasma-assisted chemical vapor deposition. High substrate temperatures $\left(800-1,000^{\circ} \mathrm{C}\right)$ are generally required for diamond growth, which limits the choice of substrate materials. In contrast, DLC films can be deposited at room temperature; they can also be virtually transparent.

\section{Advantages}

Many potential uses exist for DLCs. For instance, they can be used to reduce wear in valve guides/stems and fuel injectors; as a piston ring/bore coating to decrease wear and oil consumption; as a gear and bearing coating to increase durability and load capacities (including journal bearings); to protect glass; to improve the rollingcontact-fatigue life of cams and cam-roller followers; with air-conditioner hardware; on cutting tools; as corrosion-resistant coatings; and to boost abrasion rcsistance of vanes in gas turbines and/or turbochargers. Other applications of DLCs include protective coatings for optical components, coatings for orthopcdic use, for thermal management, and in sensors.

\section{Technical Concept}

$D$ :amondlike-carbon is a form o: amorphous carbon in which the atoms have a ranciom arrangement. With a dens:-y and harcness approaching that of diamonds, DLCs resist wear and Lower friction when sliding against other materials. These DLC coatings are produced near room temperature, eliminating the risk of damage to heat-sensitive parts. Depending on the particular process used, DLCs can be cither good electrical conductors or insulators. They may or may not contain hydrogen.

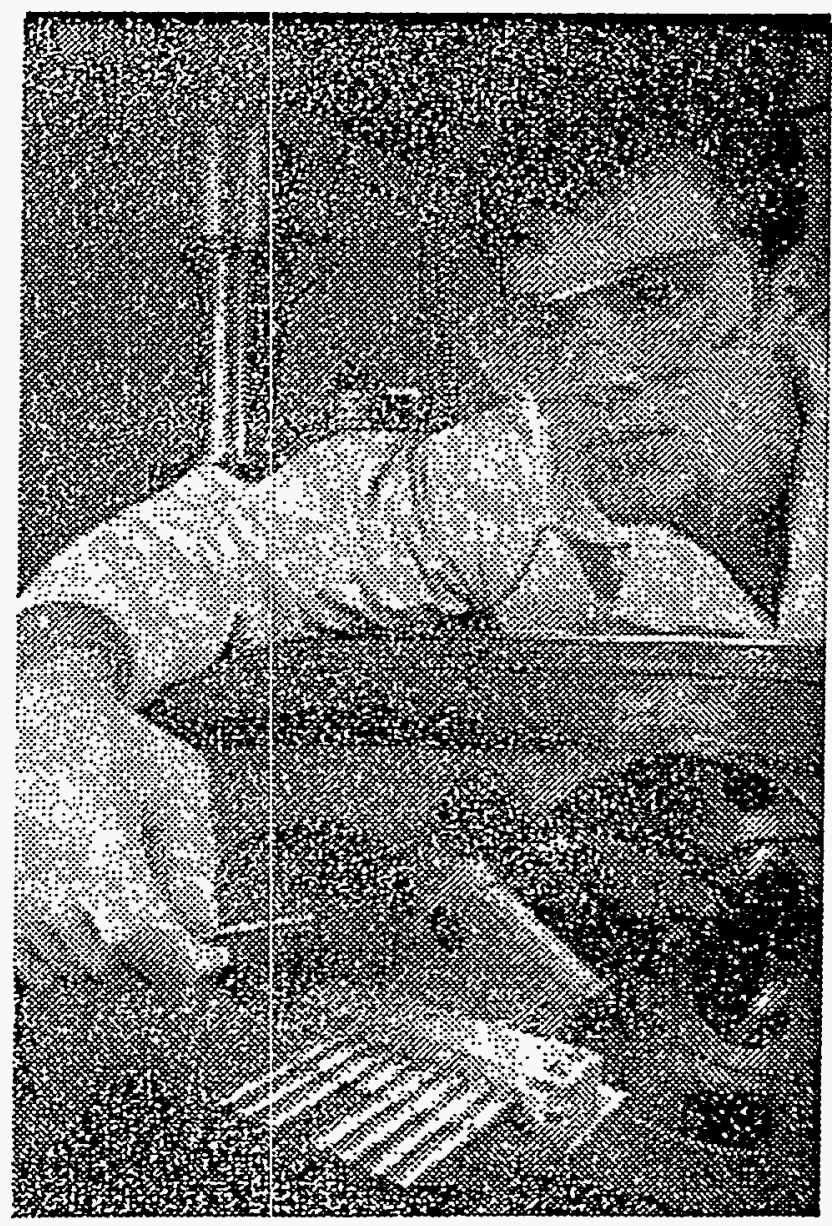

A worker instoll's automotive components into a manipulation fixture for cocting. The ports will be processed to form a DLC cooting on the surfoce, reducing wear during senvice. For uniformity, each port is rototed during the process. 
Hydrogen-free DLC is also amorphous and has a density and hardness approaching that of diamond, but it is not as well understood. Argonne is developing new coating techniques to produce these hard, wear- and corrosionresistant DLC coatings on surfaces. Hydrogenated DLCs (also known as diamondlike hydrocarbons) are produced in plasma processes, where ample hydrogen is present and where conditions are not suitable for true diamond formation.

\section{Status}

Testing at Argonne has shown friction with DLC films to be as low as 0.15 in air and 0.02 in an inert gas. More testing is needed to determine the best form of carbon and deposition method for specific engineering applications.

\section{Future Plans}

DLC coatings deposited on cutting tools, glass, plastics, and diesel-engine cylinder liners are awaiting evaluation. One goal is to produce DLC films with a variety of properties (e. g., hardness, transparency, electrical conductivity).

\section{Contacts}

For technical information, contact Fred Nichols, Tribology Section, Energy Technology Division, Argonne National Laboratory, 9700 South Cass Avenue, Argonne, Illinois 60439. Phone: (708) 252-8292; Fax: (708) 2524798.

For information on working with Argonne, contact the Industrial Technology Development Center, 9700 South Cass Avenue, Argonne, Illinois 60439. Phone: (800) 6272596; Fax: (708) 25i2-5230. 


\title{
Center for Transportation Research Explores Practical Solutions to Passenger and Freight Transportation Problems
}

\author{
The Center for Transportation Research is part of Argonne National Laboratory, one of the federal government's \\ largest research and deve!opment laboratories, located near Chicago, Illinois. Argonne conducts fundamental \\ research in the basic sciences, has a strong applied science and engineering program, and develops and \\ evaluates a broad range of energy technologies. Researchers assess the sacioeconomic and environmental \\ impacts of these technologies and government energy policies.
}

Argonne National Laboratory is operated by the University of Chicago for the U.S. Department of Energy (DOE). Although many Argonne activities are supported by DOE, a substantial number of projects are sponsored by other federal agencies, as well as state and local agencies and private industry. Argonne cooperates and maintains strong ties with industry, the recipient of the laboratory's research and analysis.

\section{Center Resources}

The independent research atmosphere at Argonne and the accessibility of many human and technical resources create an ideal setting for the Center's work. The Center operates within Argonne's Energy Systems Division, an applied science and engineering organization that cvaluates the performance, economics, and environmental effects of advanced technologies and assesses the consequences of governmental policies. The Division has a staff of more than 100 engineers, physical and social scientists, and other professionals whose expertise is drawn upon as needed.

The Center's research capabilities are also enhanced by on-site libraries of computerized models, analytical techniques, data management systems, and technical information. Off-site resources are available through the Center's participation in a nationwide network of data exchanges among national laboratories, transportation libraries and data banks, federal agencies, and universities.

The Center's staff is comprised of an interdisciplinary team of engineers, economists, planners, physicists, environmental scientists, and systems analysts with extensive experience in transportation planning and assessment. Drawn from state and local government, public and private transportation agencics, and transportation consulting tirms, the staff includes experts in national and local commodity and passenger transport systems; railroad, highway, maritime, and air transport model analysis; regulatory and legislative review; trans- portation and ecorometric modal building; new technology market forecasting; policy analysis; and critical materials assessment.

Through consulting and subcontracting arrangements, the Center also draws upon experts in the private sector and at major universities. When a project's objective is to ensure technology development capability within industry, the Center will contract a substantial proportion of the research to the private sector. Funding for the Center for Transportation Research is provided primarily through DOE. Other federal agencies and some private companies support the remaining Center activities.

\section{Center Research}

Research into a variety of passenger and freight transportation problems-and into the implications of proposed solutions-is the Center's main focus. This research includes:

\section{Analytical Methods Development}

The Center develops and applies analytical tools to improve transportation planning and provides forecasting and planning assistance to state and federal agencies and the private sector. Many sophisticated models have

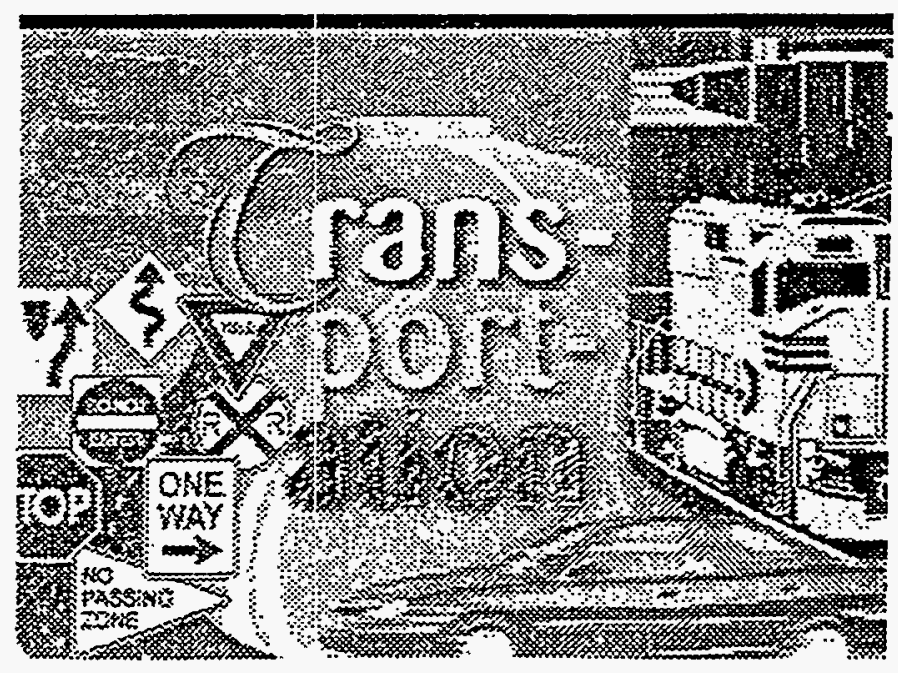




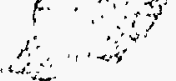

been developed or modified to assist in this work. Disaggregate transportation activity and energy use forecasting capability support the Center's activities.

\section{Alternative Fuels}

The Ccnter has a broad range of experience working with all aspects of alternative fuels, including supply, infrastructure, and delivery systems; economics; engine and vehicle technology; emissions and environmental impacts; and vehicle conversion and demonstration. Fuels studied include alcohols (methanol and ethanol); natural gas (compressed and liquefied); liquefied petroleum gas (propane); low-grade, petroleum-derived fuels; and synthetic fuels. Applications studied range from light- and heavy-duty vehicles to marine and stationary applications.

\section{Technology Evaluations}

Comprehensive impact studies are conducted on highrisk, long-term transportation technologies, with major potential benefits for the economy and the public. Rescarch has focused on using structural ceramics in vehicle propulsion systems and applying superconductors to transportation, including ship propulsion and inductively coupled vehicles. Other technologies evaluated include advanced engines such as the gas turbine, Stirling cycle, and adiabatic diesel, as well as electric and hybrid vehicles. More limited studies for near-term technologies (such as ceramic turbocharger rotors) also are undertaken to address more discrete sets of issues.

\section{Magnetic Levitation}

Research in this area has helped determine the technical and economic feasibility of high-temperature superconductors for magnetic levitation (maglev) transportation. A market analysis of high-speed maglev systems was conducted, in which an integrated maglev/airline operation was found to be the most economically viable. Energy and environmental benefits of maglev transportation have also been studied, and the status of maglev research worldwide has been evaluated. The Center continues to conduct research on maglev technology.

\section{Modal Studies}

The Center often undertakes studies that address a single transportation mode. Examples include energy conservation strategies and costs for international maritime transport and urban air-quality variations for different emissions standards for heavy-duty trucks.

\section{Policy Assessments}

The direct and indivect impacts of transportation policies are analyzed in an ongoing series of studies. This analysis produces strategies for reducing the negative effects of the policies or conflicts with other stated policy goals. Examples include analysis of the health and economic impacts on U.S. minorities when tetraethyl lead in gasoline is reduced or eliminated, and identification of the costs and energy security benefits of a transition to flexible-fueled vehicles.

\section{Contacts}

For technical information, contact Larry Johnson, Center for Transportation Research, Energy Systems Division, Argonne National Laboratory, 9700 South Cass Avenue, Argonne, Illinois 60439. Phone: (708) 252-5631; Fax: (708) 252-3443.

For information on working with Argonne, contact the Industrial Technology Development Center, Argonne National Laboratory, 9700 South Cass Avenue, Argonne, Illinois 60439. Phorie: (800) 627-2596; Fax: (708) 2525230 . 


\title{
Sulfide Ceramic Materials for Improved Batteries
}

\author{
A new class of materials offers unique properties for a variety of different engineering applications. \\ Among them could be an efficient, long-lasting bottery for electric cars.
}

\section{Opportunity}

The newly developed sulfide ceramics hold great promise for many specialized engineering applications where great strength is needed for bonding to other materials, often in highly corrosive environments. Their use is envisioned in such diverse areas as batteries, aluminum production, and nuclear waste processing.

\section{Argonne Solution}

Argonne National Laboratory researchers have based these new sulfide ceramics on nontransition metals (so called because of their place in the periodic table) rather than on conventional oxides, nitrides, or borides. These sulfides contain such nontransition metals as silicon, aluminum, lithium, calcium, and sodium. Their melting points range from $700^{\circ} \mathrm{C}$ to $1100^{\circ} \mathrm{C}$, which makes them suitable for use between $400^{\circ} \mathrm{C}$ and $700^{\circ} \mathrm{C}$.

So far, the primary application of sulfide ceramics has been in coupling metal components in electrically insulating arrangements for service in severely corrosive, high-temperature environments. Historically, development of new electrochemical devices and processes has been hampered by the inability of known ceramic sealants to fulfill these requirements. Onc of the first successful uses for sulfide ceramics was as a sealant for the first rechargeable bipolar lithium metal sulfide battery.

\section{Advantages}

Sulfide ceramics can be used in structural ceramics, porous ceramic frits (partially fused or calcined compounds), corrosion-resistant coatings, and clectrically conductive ceramic coatings. For example, they can be used as porous ceramic bodies within batteries or as substitutes for expensive metal components through the use of low-cost protective coatings. They can also be used with the molten-salt or molten-metal heat exchangers typically found in nuclear rcactors or solar energy converters.
Sulfide ceramics are also promising for probes and electrical feeds for producing and refining metals, such as aluminum and lithium, and for metallic products such as nuclear f:el. Cormponents made from sulfide ceramics improve both the safety and efficiency of such processes.

\section{Technical Concept}

As bonding and sealing agents, the sulfide ceramics form a strong reaction bond with a broad range of metal components. The sulfide ceramic melts, aggressively wets, and attacks the metal surface to bond interlocking "fingers" of metal and ceramic.

As structural components, sulfide ceramics are a composite of a fusable rnaterial enveloping solid aggregates such as oxides and other sulfides. The aggregates dictate the resulting physical properties (for example, thermal expansion, toughness, and fusion temperature flow). Other aggregate materials can change the electrical properties of the ceramic. Structural ceramics can also be engineered to reduce stresses at metal/ceramic interfaces. Finally, seals with dramatically larger diameters have been fablicated than were ever thought possible. 


\section{Status}

Argonne researchers have developed the first rechargeable bipolar lithium metal sulfide battery-an accomplishment impossible without the ceramic bonding made possible by sulfide ceramics. The bipolar configuration has by itself doubled or tripled this battery's power. Such batteries could potentially power a car for about 250 miles before needing to be recharged and could last for 100,000 miles before nece'ing to be replaced. With its high power capability, this battery could accelerate a car from 0 to 60 miles per hour in 8 seconds. It could also provide up to 5 times as much energy per pound as current battery technology while lasting 10 times longer.

\section{Future Plans}

Argonne is a partner in a three-year, $\$ 7.3$ million cooperative research and development agreement (CRADA) to devclop a new generation of batteries for electric vchicles. The research is funded by the U.S. Department of Energy's Office of Energy Efficiency and the U.S. Advanced Battery Consortium, a partnership of Chrysler Corp., Ford Motor Co., and General Motors Corp. with the Electric Power Research Institute. Argonne is working ciosely with Sait America, Inc., which has a separate contract to develop a commercial version of the bipolar battery.

\section{Contacts}

For technical information, contact Thomas D. Kaun, Chemical Technology Division, Argonne National Laboratory, 9700 South Cass Avenue, Argonne, Illinois 60439. Phone: (708) 252-5605; Fax: (708) 252-4176.

For information on working with Argonne, contact the Industrial Technology Development Center, Argonne National Laboratory, 9700 South Cass Avenue, Argonne, Illinois 60439. Phone: (800) 627-2596; Fax: (708) 2525230. 


\section{New Tribological Designs, Novel Materials, and More Effective Lubricants Will Address Future Needs of Advanced Transportation Systems}

\section{Opportunity}

Fucl-efficient, low-emissions transportation systems, such as those using internal-combustion engines or advanced gas turbines, present new challenges to lubrication engineers and materials scientists. The lubrication conditions envisioned for these systems exceed the capabilities of currently available materials and lubricants. High service temperatures, corrosive environments, and extreme contact pressures make new tribological designs, novel materials, and effective lubrication concepts necessary.

In addition, reducing both engine emissions and dependency on forcign oil will require greater use of alternative fuels, according to the U.S. Department of Energy (DOE) and other government agencies. Most alternative fuels, such as ethanol and methanol, result in corrosive wear and rapid degradation of engine oils. Thus, they are not fully compatible with current engine materials and lubricants.

\section{Argonne Solution}

Argonne National Laboratory, supported by DOE's Office of Transportation Materials, is developing new solid lubricants, lubrication concepts, and engineered tribological interfaces (ETIs) to meet the future tribological needs of advanced transportation systems.

\section{Advantages}

Wear-resistant coatings for piston rings:

- Reduce wear at higher cylinder pressures;

- Permit operation at higher ring temperatures.

Wear coatings for gears and bearing components:

- Improve durability;

- Improve load-carrying capability-permit smaller, lighter components;

- Improve performance of lightweight materials.

Coatings for cams and cam-roller followers:

- Increase rolling-contact-fatigue resistance.

Wear-resistant coatings for fuel injectors:

- Permit higher injection pressures;

- Allow operation with alternative fuels

(low-lubricity fuels, corrosion);
- Reduce wear of valve guides/stems;

- Permit tighter fits to minimize oil losses.

Wear/corrosion coatings for air-conditioning compressors:

- Improve durability of components used with $\mathrm{R}-134$ a refrigerant.

Corrosion-resistant coatings for fuel-handling components:

- Permit use of low-cost materials (e.g., polymers);

- Permit use of alternative fuels

(e.g., methanol-based fuels).

\section{Technical Concept}

Argonne has established the technical potential of diamondlike carbons (DLCs) for improving the friction and wear performance of steels and ceramics under conditions more severe than those found in current automotive applications. The next crucial steps in commercial:zing this class of coatings are to: 1) evaluate the performance of DLCs on actual automotive components, and 2) demonstrate that DLCs can be deposited on a large scale (e.g., with a process capable of coating millions of components per year).

\section{Status}

Several new solid lubricants and lubrication concepts recently have been introduced and tested over a wide range of conditions. Novel surface-engineering capabilities were developed and used to produce lubricious coatings on ceramics and high-temperature alloys to achieve low friction and wear. The synergistic effects of solid/liquid lubrication on the friction and wear performance of advanced tribomaterials are also being studied. Through proper control and optimization of deposition process parameters, excellent lubrication has been achieved over temperature and load ranges.

\section{Facilities and Equipment}

Argonne has unique canabilities and facilities for preparing ETIs and other materiais. Equipment for specimen and coating preparation include: 
- An ion-beam-assisted deposition system, capable of depositing a variety of lubricious metallic and wear-resistant ceramic coatings on both metal and ceramic substrates;

- A plasma-sputtering system, to form multi-layer lubricious oxide and metallic films on a variety of substrates;

- A microwave-plasma system, used for diamond and DLC films and cubic boron nitride.

In addition, Argonne has subcontracts with outside laboratories that provide additional equipment for prcparing ETIs. This equipment includes:

- A broad-beam, high-current, high-temperature ion implanter;

- An ion-beam-deposition system for depositing DLC films on ceramic substrates;

- A high-rate reactive sputtering system for depositing hard carbide and nitride coatings;

- An ion-beam-mixing system, used to combine lubricious films with ceramics and metallic substrates for improved lifetime and tribological behavior.

\section{Testing Capabilities}

Argonne's capabilities for tribological testing include:

- A high-temperature, pin-on-disk machine, with dry and lubricated testing capabilities to $500^{\circ} \mathrm{C}$, speeds to $8 \mathrm{~m} / \mathrm{s}$, and loads to $150 \mathrm{~N}$;

- A high-temperature, oscillating-slider test machine, permitting dry and oil-lubricated friction and wear tests to $700^{\circ} \mathrm{C}$;

- A room-temperature, pin-on-disk machine for dry and lubricated testing of wear-resistant coatings at speeds to $2 \mathrm{~m} / \mathrm{s}$ and loads to $20 \mathrm{~N}$;

- A high-temperature, pin-on-disk machine for friction and wear testing of experimental lubricants; the unit is fitted into a glovebox for close environmental control.

- A surface-texture-measuring device used primarily for determining surface topographical characteristics and wear rates of test pieces;

- A scanning electron microscope (SEM) with four clectron-probe microanalyzer attachments, used for physical and chemical analyses of friction- and weartested surfaces;
- A microindentation-hardness measuring device attached to the SEM, used for high-precision determination of near-surface hardness;

- Three exposure tanks to evaluate use of coatings as a corrosion barrier for metals, plastics, etc., exposed to aiternative fuels.

\section{Accomplishments}

Argonne developed adherent silver coatings while exploring ways to reduce ceramics wear under severe operating conditions. In bench-top tests, the coatings reduced friction by about $50 \%$, and wear by a factor of about 1,000. Related work with a self-replenishing film of boric acid that acts as a solid lubricant resulted in an P.ED 100 Award in 1991.

Seeking to improve the wear resistance of steels and titanium alloys, Argonne staff members are also developing wear-resistant titanium nitride coatings for improved tribological behavior at high temperatures. Through the use of ion-beam-mixing, molybdenum disulfide films can be applied to ceramic surfaces intended for use in cemanding conditions. And new diamond and DLC films now under development promise very low levels of friction and wear on both ceramic and metal substrates.

\section{Future Plans}

Argonne is set up to collaborate with industrial partners to coat small batches of prototype components for enduser evaluation. Small, lab-scale systems can be scaled up in size to handle the treatment of large batches of components, similar to systems currently employed to nitride and carburize steels. Argonne is seeking industrial partners to cost-share these activities to demonstrate that this class of coatings can be applied on a large-scale basis.

\section{Contacts}

For technical information, contact Fred Nichols, Tribology Section, Energy Technology Division, 9700 South Cass Avenue, Argonne, Illinois 60439. Phone: (708) 252-8292; Fax: (708) 252-4798.

For information on working with Argonne, contact the Industrial Technology Development Center, 9700 South Cass Avenue, Argonne, Illinois 60439. Phone: (800) 6272596; Fax: (708) 252-5230. 